\title{
Northern Chán and the Siddham Songs
}

\author{
Christoph Anderl and Henrik H. Sørensen
}

\section{Introduction}

In this paper, we will examine a text that enjoyed great popularity in the northwestern region of China, with multiple copies preserved in the Dūnhuáng corpus. Although probably authored during the eighth century and conveying typical Northern Chán ideas, the text was copied repeatedly in later years, evidencing that Northern Chán thinking remained en vogue in at least some sectors of the Chinese Buddhist sphere. As mentioned in the Introduction to this volume, Dūnhuáng Chán adherents were well aware of the "split" in the Chán School, resulting in the so-called "Northern" and "Southern" branches. However, in Dūnhuáng, Chán Buddhists could identify with both approaches, and seem to have had a reconciliatory attitude towards these sectarian developments. The text under discussion not only exemplifies early Chán terminology but also illustrates how Sanskrit versification appeared in material relating to Northern Chán.

The text in question is the Fóshuō Léngqié jīng chánmén xītán zhāng 佛說 楞伽經禪門悉談章 (The Siddham Chapter of the Gate of Chán [According to] the Laìkāvatāra Sūtra Expounded by the Buddha; hereafter the Siddham Song), of which several copies have been identified. ${ }^{1}$ This text was so popular that it was translated into Old Uighur several times (see Chapter Three, this volume). This suggests that early Chán thinking, concepts, and terms remained popular, an observation that is confirmed when we examine the translations in Tibetan (see Chapter Four, this volume).

The Siddham Song is ascribed to a previously unknown Chán master named Dìnghuì 定惠, who is variously said to have hailed from Dàxīngshān Monastery 大興善寺 in Luòyáng or Huìshàn Monastery 會善寺 on Mt. Sōng 嵩獄 in Hénán province. $^{2}$

1 On the various manuscripts and editions, see below.

2 Another poetic text is ascribed to Dìnghuì: the Dàxīngshān sì chánshī shāmén Dìnghuì shīcăn 大興山寺禪師沙門定慧詩㷮 (Poetic Verses by the Chán Master Śramana Dinghui of Dàxīngshān Monastery; S.5809). This text is briefly described in Demiéville and Jao, Airs de Touen-houang: $86-87$ and 330-331. There is also a Siddham Song in eight strophes in Beijing 
The Siddham Song texts appear to have originated in India as a development of standard Buddhist liturgy, but exactly how they were transmitted to China and the forms they assumed there remain unclear. What is clear, though, is that Chinese Buddhists copied — or perhaps more accurately drafted their own versions of-performative texts in which Siddham phonetics were incorporated. ${ }^{3}$ In any case, the text we are dealing with here is certainly one of this type.

Dìnghui's instructions on Chán practice have been rendered in didactic verse form, with each section featuring a string of Sanskrit sounds, appearing to emulate the sounds of spells. However, their true function is evidently to serve as metric markers for rhyming in the incantation of the text. In India,

鳥 64 (ed. in Dünhuáng gēcí, Vol. 2: 932-940), which is very similar in structure and content to the one we address here. Henrik Sørensen discusses this text in more detail in Chapter Six of this volume.

Among the Dūnhuáng manuscripts there are several "songs" and texts of the Chán School in verse form, including the Wǔgèng zhuăn-Nánzōng dìng xiézhèng wǔgèng zhuăn 五更 轉-南宗定邪正五更轉 (S.2679, S.4634, S.6o83, S.6923, S.4654, P.2045, P.2270, Beijing 咸 18, Beijing 露 6). This text is usually attributed to Shénhuì 神會 or his circle. Other Cháninspired works in verse form include the Wǔgèng zhuăn-Nánzōng zàn 五更轉-南宗贊, Wǔgèng zhuăn-dùn jiàn jìng 五更轉-頓見境 (S.6103, S.2679), Wǔgèng zhuăn-Nánzōng zàn 五更轉-南宗贊 (S.4173, S.4654, S.5529, P.2984, P.2963, Beijing 周 70, Дx1363), Qiúyīnguǒ-xiū shàn 求因果-修善 (S.5588), Zhèng wúwéi 證無為 (P.3065, P.306), Dì qũ zǔ Dàzhào héshàng Jimiè rizhāizànwén 第七祖大照和尚寂滅日齋贊文 (S.2512; Dàzhào héshàng is a reference to the Northern School master Pŭjì [651-739]), Dà Jìn Héxi Dūnhuáng jùn-Zhāng héshàng xiě zhēnzàn 大晉敦煌郡-張和尚寫真贊 (P.3972), Wǔgèng zhuăn-Jiătuō Chánshī gè zhuăn 五更傳-假託禪師各專 (S.5996, S.3017, P.3409), Qián Héxĩ dū Sēngtŏng Zhái héshàng miăo zhēnzàn 前河西僧統翟和尚邀真贊 (P.46oo; a reference to Zhái Făróng 翟法榮, who was active in the middle of the ninth century in Dūnhuáng and probably practiced a mixture of Northern and Southern Chán), Zhèng Dào gē 證道歌 (S.2165, S.4037, S.6ooo, P.2104, P.2105, P.336o; by Zhēnjué 真覺 = Xuánjué 玄覺), a “Chán Song” (Chánchāng 禪唱) in P.3156, and the Dòng zhū rén yījié 動諸人一偈 (S.3017, P.3409).

For an overview of this type of text, see Wáng Zhippéng (2005), who points out that the texts include both "Southern" and "Northern" Chán material. Some texts even seem to blend elements from the two strands of Chán. Wáng concludes that Dūnhuáng Chán was probably characterized by a reconciliatory attitude towards factional Chán. The texts contain straightforward instructions on practice and exhortations, probably aimed at a more general audience. However, none of the aforementioned works boast the metric complexity of the Siddham Song.

3 For a useful concise discussion of the history and development of the Siddham song texts, including the work under discussion here, see Zhōu Guǎngróng 2001: 141-15o. See also Mài Wénbiāo 2013, who focuses on the popular Pǔān zhòu 普庵咒. For a general overview of the introduction and development of Sanskrit writing and verse in China, see Chaudhuri 2011. 
this genre was traditionally used as a teaching device for learning the Sanskrit alphabet, pronunciation, or grammar. Knowledge of it probably arrived in China at an early date, although the level of interest in "Sanskrit studies" among early medieval Chinese Buddhists remains unclear. However, the subject gained popularity during the Táng Dynasty, triggered by increasing interest in dhäranīs and their correct pronunciation. Knowledge of Indian writing not only enabled more direct access to the original Buddhist texts but was also thought to bestow great spiritual benefits, as each sound or group of sounds was accorded specific virtues. ${ }^{4}$

There is ample evidence of the popularity of Siddham material during the Táng Dynasty. ${ }^{5}$ However, there is an ongoing scholarly debate concerning the older history of Indic writing in China. Some scholars insist that the Siddham alphabet was interpolated into the Mahāparinivāna Sütra at a later date, since no extant sūtras written in either Pāli or Sanskrit contain the Varṇamālā. ${ }^{6}$

4 According to Xuányīng 玄應's Yĩqiè jïng yīnyì 一切經音義, the Siddham primers were produced in “Brahma's Heaven” (案西域悉曇章本是婆羅賀磨天所作), and 悉謍 is explained as meaning "accomplished" (chéngjiù 成就). There was also an awareness of the difficulties involved in transferring the phonetics of Indic languages into Chinese. Quán Zhēn 全真. (T.54, no. 2134: 1216b) states: 夫欲識兩國言音者。須是師資相乘。或是西國人亦須曉解 悉昙童(懂)梵漢之語者。或是博學君子欲得作學漢梵之語者 “For those who wish to know the sounds of both countries [i.e., India and China], it should be that teachers and students develop them in sequence [i.e., that teachers should transmit them to the students]. Alternatively, people from the West should explain the Siddham to those who understand Sanskrit and Chinese. Or, to those gentlemen of broad learning who wish to engage in the study of the Chinese and Indic languages." Not only were the pronunciations of Indian sounds very different depending on Indian regional dialects and the period of transmission (as well as the numbers of basic vowels and consonants, and the syllables composed from them) but, naturally, the transcription into a Chinese phonological system based on Chinese characters posed great difficulties, too. Among the various Siddham primers there are variations between 42 and 52 letters, with the vowels (usually standardized at 14) varying between 11 and 36. (On the system of 12 vowels and 4 liquids, see Lài Wénbiāo 2013: 197.) Among the various works on the Indian alphabetical system, Zhìguăng's 智廣 Xittánzi ji 悉曇字記 has probably enjoyed the highest reputation. It is also the only fully extant Chinese work of this kind (see Zhōu Guăngróng 2001: 142).

5 The Japanese monk Annen 安然 produced a work entitled Shittanzō 悉曇藏 (corresponding roughly to Skr. Siddham koșa) in 881, and there is an entry on Xïtán zhāng in Yìjìng's travel diary (see Chaudhuri 2011: 16).

6 See Chaudhuri 2011: $23 \mathrm{f}$. 
The following manuscripts contain the Chinese text of the Xìtán zhāng: P.2204, P.2212, P.3082, P.3099, S.4583v, and Beijing niăo 鳥64 (BDooo41-1). The most complete versions are P.2212 (with some sections where the paper is torn), P.2204, ${ }^{7}$ and P.3099 (with some damage to the initial part of the text). Fragments of the text are preserved on the verso side of S.4583 (from 看內外 until the end), with census records on the recto side. There is also a fragment in the St. Petersburg collection, дхн 424 (formerly Дх492). ${ }^{8}$ There are great variations in the textual features, orthography, and arrangement across the manuscripts, especially between S.4583v and P.3082. This suggests the possibility that the extant copies are the result of extended textual transmission, and that the text was very popular and numerous copies were produced. The differences among the manuscripts are especially notable in the rendering of the phonetic passages. This may reflect attempts to adjust the phonology to new standards that had changed significantly with the introduction of Esoteric Buddhism, ${ }^{9}$ the translation of many new dhāraṇis, and the "Sankritization" of older versions of phonetic transcriptions. The effect of the song is dependent on the rhyme pattern, and as such it is of paramount importance to adjust the pattern both regionally and diachronically (i.e., in case the pronunciation of Chinese characters changed over time). The Siddham Song was critically edited in T.85, no. 2779, in which P.2204 and P.2212 were compared. However, the edition contains several mistakes and does not incorporate important information from the other manuscripts. P.3082 has been reproduced in Airs de Touen-houang (pls. 92-99). Beijing 北8405 (i.e., niǎo 鳥 64) has been edited and published with notes in the Dūnhuáng gēcí (Vol. 2: 933-940).

The song (gēci 歌詞) under discussion consists of eight sections ("strophes"), each of which consists of a recurring structure. Traditionally, a gēcí is divided into “head” (tóu 頭), “belly” ( fú 腹), and “tail” (wěi 尾). However, our Sid-

7 The copy of P.2204 is dated to 941 and has the following colophon attached: 天福隆羊辛丑 歲十二月十九日淨土著比丘僧願宗題。迷頭口上（尚）小自後再口口口堪知敦 煌懸 (縣) 公所.

8 See the Appendix.

9 This is especially evident in transcriptions occurring in texts composed after Amoghavajra (705-774). 
dham Song is structurally much more complex. ${ }^{10}$ The same rhyme pattern is employed within each strophe. Indeed, there is an "overuse" of rhymes, with each verse line ending with a rhyming character. In addition, many lines contain several rhyming characters.

The structure of the song is highly interesting, since it alternates between phonetic and semantic sections, with the two intermingling in other sections. There are three predominantly phonetic sections: One in the beginning, providing the rhyme scheme, for convenience's sake we call it the "rhyme trigger phrase"; a second one in the middle ("phonetic intermezzo"), integrating a "catch word" from the preceding semantic section, and featuring the four recurring Sanskrit liquid vowels; and a third one concluding the strophe. According to the preface, the liquid vowels were placed at the beginning of Kumārajiva's Tōngyùn 通韻 (which would have been atypical for a "Sanskrit primer," since the liquids are the most "exotic" and rarely used vowels). In the "phonetic intermezzo," the rhyme trigger phrase is repeated, introducing the second semantic part. The phonetic section at the end contains the final exhortations and the recurring "svāha" (albeit written in an unconventional way, combined with the final particle $y a$ ). The choice of phonetic elements is unique, with many of the phonetic phrases found nowhere else in extant material. They may be related to the Tongyùn, which is only partly preserved. Some of the characters in these sections probably refer to Sanskrit letters other than the four liquid vowels that occur in every verse. In fact, the Late Middle Chinese (LMC) reconstruction of the sounds suggests that some phonetically used characters might be only very loosely related to Sanskrit, and that they are rather included as non-meaningful sounds, in much the same way as "tra la la" might be used in an English song. For example, one sound sequence in Strophe 1 is 耶羅邏 (LMC/jia la la'), which also neatly fits the overall rhyme structure of $-(\mathrm{u})$ a that is used throughout the strophe.

As for the semantic sections, there are two main parts in each strophe, framed by the phonetic parts and following the rhyme scheme imposed at the beginning of each strophe. The "doctrinal" part starts with a "key phrase," after which the number of the verse is provided. The key phrase usually consists of five characters, with the final one following the rhyme scheme. Thereafter, in most sections, there are $4 \times 7$-character phrases, each of which strictly follows the rhyme pattern. These elaborate on the phrase introduced in the first line, and comment on it in "positive" terms. 


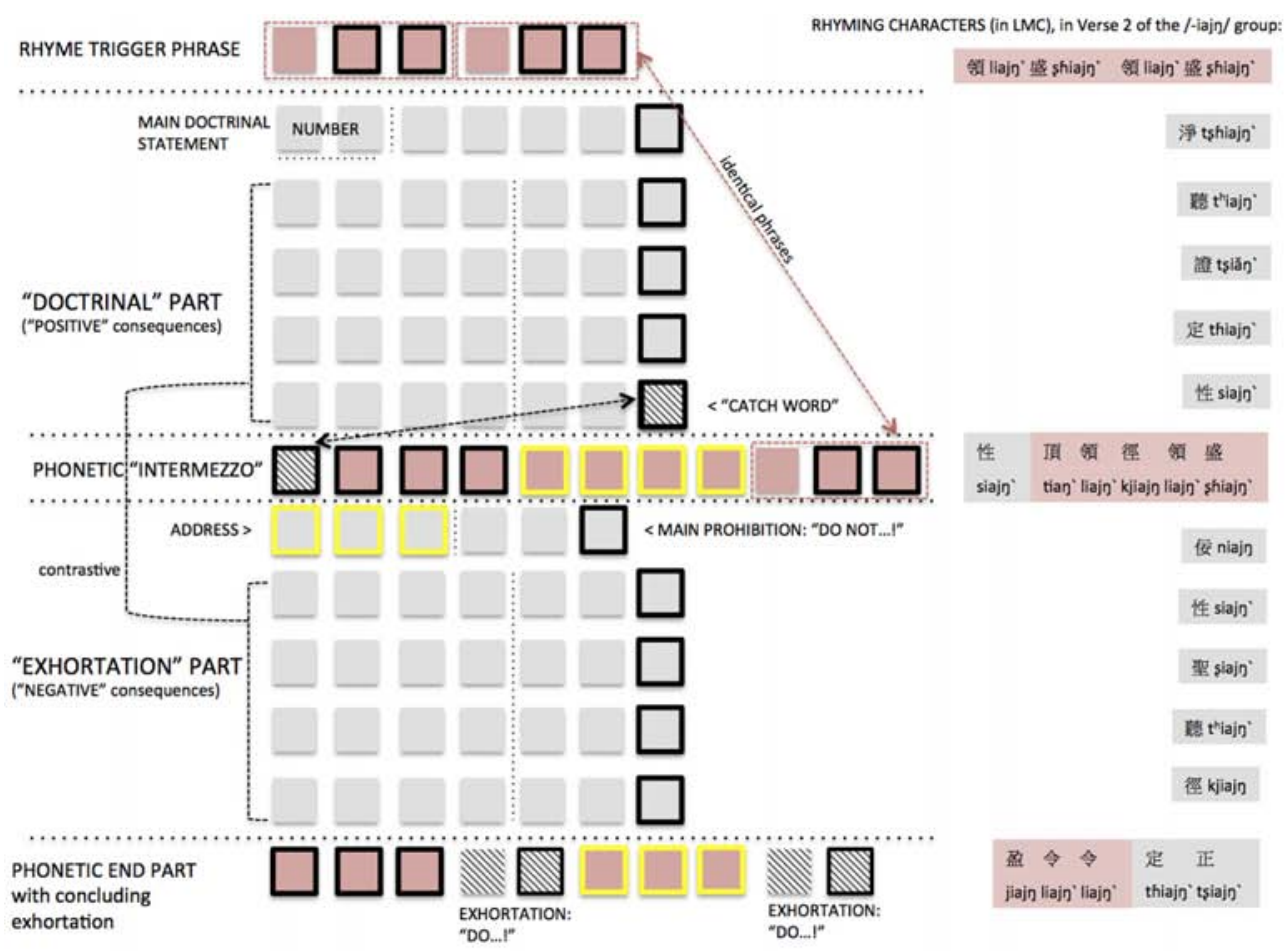

\section{Explanations:}

Phonetically used character

Semantically used character

Phonetically used character which fits the rhyme pattern

Semantically used character which fits the rhyme pattern

"Catch word", which is repeated and integrated in the middle rhyme section

Phonetically used character which is reoccurring in all verses (i.e., 魯留盧樓 $r \bar{r} / \bar{l}$, symbolizing the Siddham alphabet as the initial letters of the Tōngyùn; and 婆訶耶 svāhā preceding the final exhortation)

Semantically used character which is reoccurring in all verses (i.e., 諸佛子莫, introducing the exhortation sections)

Reoccurring identical phrase (the "rhyme trigger phrase" at the beginning of each verse, reoccuring in the middle phonetic section)

FIGURE 2.1 A schematic drawing of the structure of the Siddham Song strophes 
After the subsequent "phonetic intermezzo," there is a direct address to the "audience" of Buddhist disciples, then some prohibitions (i.e., what one should not do). Only the last two verses depart from this "Do not ..." structure. The exhortation part elaborates on the consequences for the practitioner if the prohibitions are ignored. As such, the doctrinal and exhortation parts are arranged in contrast to each other, and they usually have the same structure. (While some of the strophes divert from this structure, ${ }^{11}$ this is probably due to textual transmission difficulties and copying errors.) They strictly follow the rhyme scheme and have a four-plus-three character structure within each sequence of seven characters. There is no strict grammatical or semantic parallelism across the lines (as opposed to poems written in regulated verse).

In Figure 2.1, we have provided an analysis of Strophe 2 and visualized it with a schematic drawing. As mentioned above, the rhyming characters are excessive in both the phonetic and the semantic parts. In Strophe 2, for example, there are no fewer than 25 rhyming characters (25 percent of all characters) $!^{12}$

Several hypotheses have been proposed concerning the authorship of the text: ${ }^{13}$

1. The date of origination is between the Zhēnyuán 貞元 $\left(785^{-805}\right)$ and Yuánhé 元和 (806-820) eras, and the text was composed by the Northern Chán monk Dìnghui 定惠..$^{4}$

2. The text was composed by the Late Táng monk Shì Huán 釋寰. ${ }^{15}$

3. The text was produced during the Kāiyuán 開元 (713-741) era by Dìnghuì of the Dàxīngshàn Monastery 大興善寺. ${ }^{16}$

11 Especially Strophe 3.

12 For a short summary of the structure of the other strophes, see Kobayashi 2011.

13 Of course, we cannot exclude the possibility that Dìnghuì may have been a monk who is not referenced in any other extant source, and as such cannot be identified.

14 Rèn Bàntáng 1987.

15 See Rèn Bàntáng 1987, whose conclusion is based on information contained in the JDCDL, fasc. 9, which states that the monk was a resident of Sōng-shān; his posthumous name was Dìnghuì.

16 Ráo Zōngyí 1993, whose conclusion is based on a date on S.4583r (either 740 or 746). The Xïtán zhāng is written on the verso side of this manuscript. Ráo also argues that the author must have had a command of Sanskrit, and he identifies him as the Dìnghuì who features in S.5809, Dàxīngshàn-sì chánshī shāmén Dìnghuì zàn 大興山寺禪師沙門定惠贊. Mt. Dàxīng was a prominent translation center between the Suí and the Táng. 
4. Zhōu Guăngróng (2001: 143) points out that the text must have originated after the composition of the Tonngyùn 通韻 (traditionally ascribed to Kumārajīva). He assumes a date of composition after 830 on the basis of textual features. ${ }^{17}$ After analyzing information provided in the JDCDL and comparing it with the preface of the Xïtáng zhāng, he cites Shì Huáng as the author.

As stated above, the identity of Dìnghuì of Huìshàn Monastery (or Dàxīngshān Monastery) has long remained a mystery. ${ }^{18}$ As far as we have been able to ascertain, none of the traditional sources on Chán mentions a master by this name residing at Huìshàn Monastery on Mt. Sōng. There are other Chán monks with this honorific name including the celebrated Guīfēng Zōngmì 圭峰宗密 (778840), but it is difficult to make a case for him or any of the others being our Dìnghuì as they all lived in later times, as can be readily established on both historical and doctrinal grounds.

As far as we know, only Jao Tsong-yi and Paul Demiéville have taken serious note of Dìnghuì (in their study of the hymns and eulogies found at Dūnhuáng). ${ }^{19}$ However, even they remain uncertain regarding his identity and the precise religious context in which he operated. More recently, Chinese scholars such as Rèn Bàntáng 任半塘 and Zhōu Guăngróng 周广荣 have suggested that Dìnghuì was the Chán monk Huánzhōng 寰中 (78o-862). ${ }^{20}$ However, this identification is certainly erroneous, for several reasons. Firstly, Huánzhōng was a Southern Chán monastic—a direct follower of Bǎizhàng Huáihǎi 百丈懷 海 (730-814), descending from the Hóngzhōu School of Mǎzǔ Dàoyī 馬祖道一 (709-788). ${ }^{21}$ Secondly, none of the early sources on Huánzhōng mentions that he composed Siddham songs. Thirdly, in our opinion, Dìnghui's song clearly dates from the first half of the eighth century: that is, before Huánzhōng was born. Fourthly, and most significantly, there are no traces of Southern Chán in the Siddham Song under discussion. On the contrary, it reflects mainstream

17 In addition, Zhōu Guăngróng points out that the text specifically states that the four liquid vowels constitute the beginning of the list of vowels. This arrangement seems to have been employed for the first time in the Nièpán jīng xìtán zhāng 涅槃經悉曇章.

18 Contrary to what one might expect, neither Tanaka Ryōshō nor Yanagida Seizan -in their otherwise excellent studies on the history and literature of early Chán-pays much attention to Dìnghuì. Bernard Faure 1989: 58-6o discusses him briefly, but remains unclear about his identity.

19 Cf. Demiéville and Jao 1971: 86-87, 330-331.

20 Cf. Dūnhuáng gēcí, Vol. 2: 932, 940; Zhōu Guăngróng 2001: 143-144.

21 For Huánzhōng's biographical entry, see JDCDL, T.51, no. 2076: 263c-264a; see also T.5o, no. 2061: 778a. 
Northern Chán in its purest form. Hence, our Dìnghuì could not have been Huánzhōng, so we must look elsewhere for an accurate identification.

In 2010, Takise Shōjun published a concise study on the Siddham Song, focusing on the date of compilation. He notes the text's close relationship to Northern Chán thought ${ }^{22}$ as well as parallels found in Shénhui's criticism of early Chán thought before suggesting that Shénhuì might have been familiar with the Siddham Song before launching his criticism in 732 . Hence, he dates the text's composition to around 720 . Takise also emphasizes the close relationship with Jìngjués Léngqié shīzi jì-which similarly constructs a patriarchal lineage between Gunabhadra, the translator of the Lankāuvatāra Sütra, and Bodhidharma-and argues that the compiler may well have been in the latter's circle of Chán adherents.

The contents of the manuscripts mentioned above and other primary sources all suggest that the author's doctrinal stance belonged firmly within the Northern Chán tradition. In fact, the Siddham Song contains almost every doctrinal feature that characterizes this denomination of Chán, including references to its main meditation practices, such as "meditating on purity" (kànjing 看淨), "contemplating/viewing the mind" (kànxin 看心), "one thought/onepointedness (of mind)" (yiniàn 一念), the "contemplative method of being apart from mentation" (xīn lí chánmén guān 心離禪門觀), and being “without recollection" (wúniàn 無念). Most conspicuously, the reference to "sweeping of the mirror" (mójing 磨鏡) links the text directly to Shénxiừs famous verse in the Platform Scripture and, by extension, his lineage. ${ }^{23}$ The statement on the difference between samsāra and nirvāna as well as the overall gradualist and dualistic attitude towards practice that is evident throughout the work similarly identify the text as belonging to Northern Chán. Interestingly, the doctrinal and practical stance of the Siddham Song, with its overwhelmingly gradualist approach, seems to justify Southern Chán adherents' traditional insinuations against and criticism of Northern Chán. ${ }^{24}$

Having established the sectarian provenance of Dinghuì on the basis of the doctrines that feature in the Siddham Song, we must now attempt to identify his historical and geographical milieu. The manuscripts relating to Dìnghuì state that he was a Chán master of either Dàxīngshān Monastery or Huìshàn

\footnotetext{
22 For more details, see the translation part.

23 Cf. T.48, no. 2007: 337c.

24 This ought to cause us to look critically at Yanagida's assertion that Northern Chán was as "sudden" as Southern Chán. Careful appraisal of the sources indicates that the Shénhuìs criticism of Northern Chán, as well as that found in the Platform Scripture, was justified, at least to a certain extent.
} 
Monastery on Mt. Sōng. To the best of our knowledge, there has never been a Dàxīngshān Monastery on Mt. Sōng, although there was a major, well-known monastery of that name in Luòyáng proper. ${ }^{25}$ By contrast, there was-and still is-a Huishàn Monastery on the mountain. Hence, we suggest that whoever wrote down the Siddham Song confused the two institutions and that the master was probably a resident of Huìshàn Monastery. As this was also the residence of Pǔji 普寂 and Yīxíng 一行, Dìnghuì's historical affiliation with Northern Chán seems rather obvious.

As the Siddham Song is of Northern Chán provenance and reflects some influence of Esoteric Buddhism in its use of versifying Siddham, we suggest that it was composed after Śubhākarasimha started to popularize Esoteric Buddhist rituals in northern China. Earlier Northern Chán scriptures (i.e., primarily the works ascribed to Shénxiù) show no Esoteric Buddhist influence whatsoever. ${ }^{26}$ Consequently, we may conclude that Dìnghuì flourished after the death of Shénxiù, probably around the time when Śubhākarasimha and Vajrabodhi were teaching in the Twin Capitals. As we have already shown, the text of P.2212 must have been composed before Shénhuì launched his critique in 732. Moreover, it seems all but certain that Dìnghuì was at least acquainted with Pǔjì and Yixxíng. Indeed, he was probably identical with one or the other. However, as "Dìnghuì" was seemingly either an honorific or a sobriquet, it is unlikely that Pǔjì is our man because we already know his honorific_-Dàzhào"—as this appears on an extant stele inscription. ${ }^{27}$ In addition, there is no evidence that Pǔjì ever incorporated Esoteric Buddhist elements or Siddhaṃ into his Chán teachings.

Yīxíng's own stele inscription gives his posthumous title as “Dàhuì 大慧. It is unlikely that "Dinghui" is simply a modified or corrupted version of this honorific. However, in the Dà-Táng Dōngdū Dàshèngshàn sì gù Zhōng-Tiānzhú guó Shànwúwèi sānzàng héshàng bēimíng bìngxù 大唐東都大聖善寺故中天竺國善 無畏三藏和尚碑銘並序 (The Central Indian Tripitaka Master, Venerable Śubhākarasimha's Stele Inscription from the Dàshèngshàn Monastery in the Eastern Capital of the Great Táng, with Preface), the celebrated scholar Lǐ Huá 李華 (715766) gives Yìxíng’s style name as "Dìnghuì." ${ }^{28}$ We also know that Yìxíng dwelt on

25 For a useful presentation of the history of the Dàxīngshān Monastery, see Wáng Yàróng 1986. For an overview of the great Esoteric Buddhist monasteries and their functions under the Táng, see Chen 2011: 286-293.

26 Shénxiù's teachings and the works associated with him are discussed in McRae 1986: 148234 .

27 For a survey of Pǔji's life and career, see ibid.: $65^{-67}$.

28 Cf. T.5o, no. 2055: 291b. 
Mt. Sōng for a number of years and that he studied Northern Chán under Pǔjì, which would explain the strong influence of that tradition in the Siddham Song. Therefore, he seems the most likely author of the text. Moreover, as it contains little in the way of Esoteric Buddhism proper, we may go further and suggest that he composed it prior to his exposure to the teachings of Śubhākarasimha in the 720 .

Text Edition and Translation ${ }^{29}$

5.1 Title

佛說楞伽經禪門悉談章并序 30

5.2 Preface

諸佛子等合掌至心聽。我今欲說大乘楞伽悉談章。悉談章者, 悉談昔大 乘在楞伽山。因得菩提達摩和尚。宋家元年從南天䇥國。將楞伽經來至 東〉都。跋陀三藏法師奉諮翻譯。其經總有五卷合成一部。文字浩汗意義 難知。和上慈悲廣濟郡品。通經問道識攬玄宗。窮達本原皆蒙《指受。又 蒿山會善沙門定惠翻出悉談章。廣開禪門不妨慧學。不著文字並合秦音。 亦與鳩摩羅什法師通韻。魯留盧樓為首。

\subsubsection{Textual Annotations}

- The T. edition (included in CBETA and SAT) follows P.2212, with comparisons to P.2204. The orthography of P.2204, although neatly lined up, is rather strange and clumsy and gives a somewhat "non-Chinese" impression. In addition, the copyist might have used an unusual writing utensil.

- Děng 等 is functioning here as plural marker, as frequently in Buddhist texts, rather than meaning "and so on," "and others," etc.

- 悉談章者悉談昔大乘在楞伽山: the T. editors (who use P.2212 as basic text) are mistaken here. T. has 者悉談昔大乘在楞伽山, which does not make sense. P.2212 has repetition markers 2 after the final three characters (悉

29 In the edition, passages that differ in the various manuscripts are marked with grey shading and commented upon. Longer passages that show major diversions are in boldface. We are grateful to Sven Osterkamp (Ruhr University, Bochum) for his many useful comments on a draft version of the edition. We also wish to thank Lín Jìnghuì 林靜慧 (DILA, Taiwan) for her comments on some of the variant characters. P.2212 and P.2204 have previously been critically edited and encoded in the Ghent University Database of Medieval Chinese Texts.

30 The first column of P.2204 consists of the title, with 并序 ("with preface") added in small characters. 
談章) of 我今欲說大乘楞伽悉飞談四章心 to indicate that these three characters should be repeated as one phrase. As such, the passage is resolved properly, topicalizing 悉談章 with 者: 我今欲說大乘楞伽悉談章。悉談章 者, 昔大乘在楞伽山 “Today, I wish to expound [...] As for 'Xītán Chapter', [it means] that formerly the Great Vehicle was situated on the Lankā Mountain." P.3099 erroneously includes 者 twice in the passage: 我今欲說大乘楞 伽悉談章者。悉談章者, 昔大乘在楞伽山.

- Boldface indicates the sections of P.3099 that are missing due to paper damage.

- T.: 宋家元年: P.2204 and P.2212 have the preposition 於: 於宋家元年 “In the first year of the Sòng-jiā era."

- T.: 笈: P.2204 and P.2212 have the homophonous 竹.

- $\rangle\rangle_{\ldots} \ldots\langle\langle$ marks any passage that is partly preserved in the fragment дXн 424r (formerly: Дx492); the page is torn in the middle (see the Appendix).

- After 都, P.2204 has a break of two empty spaces. ДXн 424r:硣.

- 跋陀 is missing in P.2204.

- 合成一部 is missing in P.2204.

- 浩汗 (P.2204): the variant 浩垾郖 is used in P.2212 and дXH 424r.

- Jùnpı̌n 郡品 (P.2212): P.2204 has 群生 for “sentient beings." Also note the variants 第 (P.2212) and (ДXH 424r) for ji 濟 (P.2204: 病).

- 玄: following P.2204; P.2212 uses 懸 as phonetic loan for 玄 (“mysterious; profound"); (дхн 424r). These are commonly exchanged characters in Dūnhuáng manuscripts and have a long history of phonetic exchange.

- 原: ДXH 424r has 願 圆 ("vow, wish"). There seems to be a problem with the preceding character, which is marked as "deleted" with (maybe, 願 was originally copied twice?).

- 會善沙門定惠 (P.2212): P.2204 has only 慧; however, on the left side of the preceding 又松山, the following characters are inserted upside down: 會善 沙門定 (correcting the phrase to: 會善沙門定慧).

- 亦: following P.2204 and P.3099 妥 (亦), which makes more sense than 彼 in T. The characters 音亦與鳩 are missing in P.2212 because of paper damage.

- 魯留: the manuscripts use variants for the recurring phonetic passages (see, for example, P.2212 and P.22O4 to the right). In both manuscripts, the first of these characters is somewhat problem-

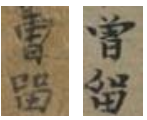
atic: in P.2212 it resembles 曹, while in P.2204 it resembles 曾, rather than 魯. However, the reference to 魯 is clear. 


\subsubsection{Translation}

All of you sons (i.e., disciples) of the Buddha! Clasp your hands [in ãñjali] and listen with a concentrated mind (lit. "utmost mind"). I now wish to expound the Siddham Chapter (or: Primer) of the Mahāyāna Laìkāvatāra [Sūtra]. As for the Siddham Chapter, formerly the Mahāyāna [Scripture] was situated at the Lañkā Mountain (i.e., Sri Lanka), whence it was obtained by the Venerable Bodhidharma, who brought the Là்kāvatāra Sūtra during the first year of the Sòng-jiā era (i.e., 424 CE) from South India to the Eastern Capital (i.e., Luòyáng). ${ }^{31}$ The Tripițaka and Dharma Master Gunabhadra respectfully consulted and translated [the sūtra]; he assembled the altogether five fascicles into one volume (bù). The written text is extensive and difficult to comprehend. The Venerable [Master] was compassionate and [aimed at] universally saving the sentient beings; he penetrated (i.e., thoroughly understood) the scripture, investigating the Way (i.e., Buddhist truth), and his consciousness (i.e., mind) grasped the subtle doctrine (xuánzōng 玄宗). ${ }^{32}$ Fully arriving at (i.e., understanding) the origin, they (i.e., the sentient beings he instructed) all received [the sūtra's] teaching. Furthermore, there was also the śramānera Dìnghuì from Huìshàn [Monastery] on Mt. Sōng, who rendered ${ }^{33}$ [the sūtra into] a Siddham primer, widely opening the gate (i.e., teaching) of Chán, not impeding the study of pra$j \tilde{n} \bar{a}$, and not relying on written texts. ${ }^{34}$ He harmonized it (i.e., the sounds of the Sanskrit) with the sounds of Qín (i.e., the Chinese pronunciation), corresponding to Dharma Master Kumārajīva's Tōngyùn, the heading ${ }^{35}$ of which was

$31 \quad$ We interpreted the phrase with jiāng as disposal construction.

32 In classical Chinese literature, qióngdá 窮達 is usually used nominally, meaning something akin to "failure and success." However, we doubt that this is the meaning here. The phrase structure suggests that the element after 窮達 is the object of a transitive verb. Checking Buddhist literature, an object with positive connotations is usually attached after 窮達, e.g., 故須窮達幽旨妙得言外 (“Therefore, one should fully (lit. exhaustively) arrive at the mysterious teaching, and subtly attain what is beyond words"; Gāosēng zhuàn 高僧傳, T.5o, no. 2059: 383aog). Cf. also 經由「守心」、「安心」的功夫, 達到我 所心滅, 穹達法性, 即得涅槃 (“Based on efforts [in the methods] of 'preserving the mind' and 'pacifying the mind,' one arrives at (i.e., attains) that the mind which assumes ownership [of things] is extinguished, and the Dharma-nature is fully penetrated; as such, one attains nirvāṇa"; see Huáng Qīngpíng n.d.).

33 Zhōu Guăngróng 2001: 144 points out that 翻出 does not necessarily mean "to translate" here (providing examples from other texts), but rather "compose (a song)" by transforming teachings based on the Lañkāvatāra Sūtra into a popular song in order to instruct the common people.

34 It is interesting to find this famous dictum here, indicating the widespread notion of Chán Buddhism as constituting a "special transmission beyond the words of the canonical scriptures."

35 Cf. T.85, no. 2779: 536a; Dūnhuáng gēcí, Vol. 2: 940. 
lǔ-liú-lú-lóu (i.e., the four liquid vowels $r \bar{r} \underline{\underline{r}} ! \prod^{3},{ }^{36}$ which headed the list of vowels in the Töngyùn). ${ }^{37}$

\subsubsection{Comments}

This introduction to the Siddham Song reveals a few basic points concerning its perceived origin, transmission, and development up to and into the Táng. It claims that the basic ideas concerning its introduction to China and subsequent transmission took place via the Chán Buddhist tradition, as indicated by the central position accorded to its legendary founder Bodhidharma, the Lañkāvatāra Sūtra, and, by extension, the Indian monk and translator Gunabhadra. When taken together, these features indicate a Buddhist context that we now associate with the so-called Northern School of Chán, and specifically

36 It is quite remarkable that the four liquid vowels were arranged at the beginning, since traditionally they concluded the list of vowels. Understandably, translators had problems with these four letters:

Conventionally, these four liquid vowels come after ū and before e. It might have been difficult for the foreign monks to convince their Chinese collaborators of the vocalic character of their four liquid vowels. Apparently Fa-hsien also failed. So they were shifted to the end saying that they were used rarely. Had the Varṇamālā been a part of the sutra [i.e., the Mahāparinirvāna Sütra] from the very beginning, then this manipulation would not have been done. The Chinese, however, were very much aware of their conventional position. (Chaudhuri 2011: 23)

The Japanese Buddhist catalogue Rokugekyō-tō mokuroku 錄外經等目錄 (An Index of Non-canonical [i.e., not listed in the Käiyuán Canon] Scriptures), compiled by an unknown Japanese monk, contains a reference to a Luóshíxitán zhāng 羅什悉昙章 (Kumārajīva's Siddham Text), which in all likelihood is the book to which our text refers (cf. T.55, no. 2175: 1112a). In S.1344, there are fragments of a text with the title Jiümóluóshí făshī tōngyùn 鳩 摩羅什法師通韻 (Comprehensive Rhymes of the Monk Kumārajīva) as well as a reference to the Xìtán zhāng. In the Tōyō Bunko collection (Tokyo), there is a copy with the title Nièpán jing xītán zhāng 涅槃經悉昙章, dated 862 and supposedly written by Kumārajiva (for the arrangement of vowels there, see Chaudhuri 2011: 25). Most scholars believe that this is not an original work by Kumārajīva, partly because of its terminology, which was invented after Kumārajīva's lifetime (see ibid.: 26). Chaudhuri suggests that Kumārajīva did write both works, but the Nièpán jīng xitán zhāng was lost and "reinvented" at a later date. This fabricated version was then exported to Japan. In the case of the Töngyùn, Chaudhuri asserts that it was dramatically altered over the years as successive generations of students added notes and technical terminology that eventually became part of the text.

The Japanese catalogue also mentions a Zhānbō-chéng xītán zhāng 瞻波城悉昙章 (Siddham Text from Campāi [?]; cf. T.55, no. 2175: 1112a; Campā refers to a country or city on the banks of the Ganges, to the south of Vaiśālī). The fact that the catalogue bears a postscript with the date 930 CE (Enchō 8) indicates that the aforementioned two works were exported to Japan between the late Táng and the early Five Dynasties eras. 
the transmission lineage outlined by Jìngjué 淨覺 in the Léngqié shīzīji 楞伽師 資記. Furthermore, the celebrated translator Kumārajīva is credited with originating the versifying use of Sanskrit that we find in this type of song. The introduction also suggests that the main tenets of the Lankāvatāra Sütra (a highly arcane text) were rendered into a rhyming song in order to make them accessible to the common people and lead them to realization.

\section{$5 \cdot 3 \quad$ Strophe 1}

頗邏隋頗邏墮

第一：捨緣清淨座。万事不起真無我。直進菩提離因果。心心寂滅無殊

禍。念念無念當印可。摩底利摩魯留盧樓頗羅墮

諸佛子莫嬾墮自勸課。愛河苦海須度過。憶食不喰常被餓。木頭不攢不出 火。

耶羅邏端坐。娑訶耶莫臥。

\subsubsection{Textual Annotations}

- 触頗邏墮: P.2212 has repetition markers instead of the second 頗邏墮. 頗邏 墮頗邏墮 is missing from P.2204, which structures the text differently, taking 第一, 第二, as headers (usually on top of the columns) and inserting spaces before the exhortations starting with 諸佛子莫 (“All you sons (i.e., disciples) of the Buddha, do not ..."). P.3099 uses repetition markers and has no spaces either above or below; instead of 囉 it has 羅.

- 座: P.2212 has 坐 ${ }^{-}$, routinely exchanged in Dūnhuáng manuscripts.

- The manuscripts have for 萬.

- 無我直進 is missing in P.2212 (torn paper).

- 無: all occurrences in P.2122: - 6 ; P.2204 uses both 無 and 无.

- 菩提: P.2204 has the copying mistake 菩薩提; the tiny deletion marker $\boldsymbol{F}$ is visible to the right of 薩.

- 念當印可 and 過 are nearly unreadable in P.2212 because of paper damage.

- 不喰常被餓: in P.2212, 喰常 is added to the right of the column.

- 羅邏 (P.2212): P.2204 has 羅羅 露; indeed, the first character contains a tiny additional $\square$ on the upper left: 囉羅. P.3099 also has 囉羅. 
$5 \cdot 3.2$ Translation

頗邏墮頗邏墮

[LMC: $\mathrm{p}^{\mathrm{h}}$ ua la' thua' $\mathrm{p}^{\mathrm{h}}$ ua la' thua']

Firstly, one must forsake [all activities that create] conditions and [instead practice] pure sitting.

[Thus,] the myriad phenomena will not arise [and this is] true no-self.

One will directly enter bodhi and become free from cause and effect (i.e., the results of karma).

Thought-moment after thought-moment one will enter quiet extinction, and there will be no calamity.

Thought after thought [dwelling in] no-thought, one shall [have enlightenment] approved.

摩底利摩魯留盧樓頗羅墮

[LMC: mua tiaj' li’ mua luă liw luă ləw p $\mathrm{p}^{\mathrm{h}} \mathrm{ua}$ la` thua']

All you sons (i.e., disciples) of the Buddha! Do not be lazy but exert yourselves!

The river of affection and ocean of suffering - [you] should cross [them]. If one thinks about food but does not eat-then one is constantly suffering hunger.

Wood not being accumulated, one does not (i.e., is unable to) generate fire.

耶羅邏 [LMC: jia la la'] Sit upright in meditation! Svāhā-ya [LMC: sa: xa jia]! ${ }^{38}$ Do not lie down!

\subsection{Strophe 2}

只領盛只領盛

第二：住心常看淨。亦見亦聞無視聽。生滅兩亡由未證。從師授語方顯 定。見佛法身無二性。

性頂領徑魯留盧樓只領盛

諸佛子莫瞋侫。三毒忽起無佛性。癡狂心亂惱賢聖。眼貪色塵耳縛聽。背 却天堂向惡徑。盈令令修定。娑訶耶歸正。

38 In standard spells or dhāraṇis, "svāh $\bar{a}$ " is a final, effectuating expression with a meaning akin to "so be it," "effectuate," etc. Here it is used in much the same way as signaling the end of each strophe (svāhāa-ya). 


\subsubsection{Textual Annotations}

- Also, here, P.2212 uses repetition markers. P.2204 has 質 for 只 and the phrase 質領盛(成) is also the final phrase of the last section, with the new section starting with 第二. In addition, it is noteworthy that there are repetition markers only after the first two characters; strictly speaking, the phrase has to be read 質領質領盛 (which obviously was not the intention). P.3099 also has 質 for 只 and does not feature any spaces or new column in order to structure the text.

- 亦 (P.2122, P.3099): this is interesting, since the "standard" character is used for the first 亦, whereas the second 亦 uses the current variant 急.

- 亡: variant $\mathbb{E}(\mathrm{P} .2212)$.

- 定見: missing in P.2212 (paper damage).

- Repetition marker for the second 性 in P.2212.

- 佛 (仏) is hardly readable in P.2212.

- 只: in contrast to the same phrase above, P.2204 and P.3099 also use 只 here. After the phonetic phrase, there is a space in P.3099 and 諸佛 starts with a new column.

- 瞋 (P.2204, P.3099): 嗔 (P.2212).

- 亂 (all occurrences in P.2212): 乱 \&6; P.2204 and P.3099 prefer the variants

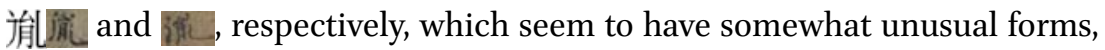
especially the left parts of the characters; however, 亂 is a character with many differently shaped variants.

- 縛: P.2204 has 莫, which does not make sense (maybe a copying mistake triggered by the "context" as there is a 莫 in the column to the right). P.3ogg has 真, which also seems to be a mistake. It is surprising that the manuscripts differ so significantly with regard to this phrase.

- 背: in P.2204, the character 皆 looks very similar to 皆, but it should probably be interpreted as 背, given the context.

- 却 (P.2212): 何 (P.2204); the character is unreadable in P.3099 (paper damage).

- 徑 (P.2212): 境 (P.2204, P.3099); “evil path" versus “evil realm.”

- 令: the T. editors interpret this as 今; however, we think it should be read as a somewhat careless 令, also in P.2212; P.2204 and P.3099 have 令令 (with the second 令 indicated by a repetition marker).

- 修: P.3099 has the variant 得. 
5.4.2 Translation

只領盛只領盛

[LMc: tşi liajy` shiajy 'tsi liajy ‘shiajy’]

(質: LMC: $/ \operatorname{tri}^{\mathrm{h}} /$ )

Secondly, one shall settle the mind and constantly contemplate purity.

Then, when seeing as well as hearing, there will be nothing to look at and [nothing] to listen to.

Birth and death will both disappear, [but] still not yet realizing [enlightenment] (or: despite not yet being enlightened). ${ }^{39}$

Having received instructions (lit. words) from the teacher, only then ( fāng 方) one will be able to [manifest] concentration (samā $d h \bar{\imath})$.

Seeing the dharmakāya (i.e., dharma body) of the Buddha as being without duality (èr xing 二性).

Nature! (性)頂領徑魯留盧樓只領盛

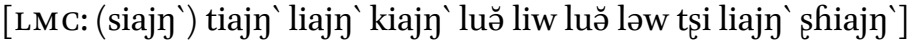

All you sons of the Buddha! Do not fall in rage and flattery!

[When] the Three Poisons suddenly arise [then] there is no Buddha-nature. The state of mental confusion ${ }^{40}$ is an annoyance to sagely persons.

[In this state] the eyes have desire for sensual forms (or: colors), and the ears are attached to hearing.

By turning one's back to the halls of Heaven, one faces towards evil circumstances (i.e., evil paths of rebirth).

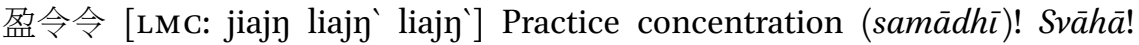
Return to the correct (or: rely on what is correct)!

39 We interpret 由 (“depend on") as a phonetic loan for 猶 ("still”) — a common substitution. The phrase "not yet realized" is contrasted with the following statement that it is necessary to follow the instructions of a teacher (in order to reach enlightenment). However, the passage is problematic.

40 Chīkuáng xinnluàn 癡狂心亂 (lit. "ignorant-crazy-mind-disturbed”) is a set phrase in Buddhist Vinaya literature, indicating a state of total mental confusion and insanity in which one is unable to control one's thoughts and deeds, and as such is not responsible for any transgressions (fàn 犯). See especially T.22, no. 1428 and T.23, no. 1442. 


\subsection{Strophe 3}

\section{嗄浪養嗄浪養}

第三：看心須併儻。掃却垢穢除災障。即色即空會無想。妄想分別是心 量。體上識體實無謗。

謗底利謗魯留盧樓(pb:T_T85n2779_0536b)嗄浪養

諸佛子莫毁謗。一切皆有罪業障。他家聞聲不相放。三寸舌根作沒向。道 長說短惱心王。心王不了說短長。來生業道受苦殊。羊良浪併當淨掃。 堂中須供養。

\subsubsection{Textual Annotations}

- 嗄浪養: repetition markers in P.2212, P.2204, P.3099; the new section starts with a new column in P.2212 and is preceded by an empty space in P.2204 and P.3099. The first character 嗄 腹 of P.2212 differs in P.2204 and P.3099: 復便 (?). In handwriting, 復 is structurally similar to 嗄.

- 儻: not discernible in P.2212 due to damage.

- 謗: interestingly, no repetition marker is used here.

- Repetition marker for second 心王.

- 良: looks like 浪 in P.2212.

- 謗 (P.2212): missing in P.2204.

- 利 (P.2212, P.2204): 裏 (P.3099).

- 嗄 (P.2212): 復 in P.2204 and P.3099.

- 佛子 (P.2212): 子佛 (P.2204); the reversed sequence is corrected by the marker $\checkmark$ to the right of the characters. From 諸佛子 onwards, the text is extant in P.3082.

- 毀: P.2204 uses the interesting variant 㥗 (similar to a character form used in P.216o). ${ }^{41}$ In P.3082, the character ( ) is nearly unrecognizable.

- 聲: in P.3082 there seems to be a 時 ( ).

- 沒: P.3082 has 罪.

- 說短: in P.2204, there is a space between these two characters.

- 惱: P.3082 has the strange form

- 良浪 (P.2212, P.2204): the T. editors mistakenly have 良良.

- 併當 (P.2212): 屏儻. ${ }^{42}$

- 須: the T. editors have misinterpreted the character as 頃.

- 羊良浪併當淨掃堂中須供養: these final phrases in P.2212 and P.2204 are problematic because 掃 does not fit the phonological profile (see below) and

41 See Huáng Zhèng 2005: 167.

42 On 併當, see Zengo jiten: 414; meaning "to deal with/settle (a problem); put in order; get rid of" (also written as: 拼當, 屏當, 摒當, etc.; appearing in early vernacular literature such as Zǔtáng ji 祖堂集 and the biànwén 變文 transformation texts). 
the "obligatory" 娑訶 is missing. Unfortunately, this section is not preserved in S.4583v. P.3099 has the same phrasing as the other manuscripts, except 併: 屏 and 當: 儻. P.3082 has 王良量併當淨掃堂中供養. Concluding, there is a textual problem with this passage as it fits neither the rhyme scheme nor the overall structure.

\subsubsection{Translation}

嗄浪養嗄浪養

[LMC sa: lay jiaj']

(復 LMC: fhjyw')

Thirdly, when looking at the mind [in contemplation], it is necessary to get rid of [obstacles] ${ }^{43}$

[Therefore, one must] sweep away all dirt, getting rid of calamities and obstacles (or: when interpreted as a dissyllabic word, just "calamities").

Form is the same as emptiness, [when this is realized] one will be able [to attain] no-thought.

43 Kànxīn (kànxīn) 看心, one of the key terms in early (Northern) Chán, is closely related to guānxin 觀心 (“contemplate the mind"). A description of this method appears in the Rùdào ānxinn yào fāngbiàn fămén 入道安心要方便法門, which is included in Jìngjué 淨 覺 (683-?)'s Léngqié shīzīji 楞伽師資記, one of the earliest transmission texts of the Chán School that was discovered among the Dūnhuáng manuscripts. The Rùdào ānxīnyào fāngbiàn fămén is regarded as a product of Dàoxìn, who retrospectively became known as the "Fourth Patriarch" of the Chán School. In this text, kànxin is described as "to view the mind which is neither within nor without and which is none other than Buddha" (Chappell 1983: 99). The term is also closely connected to the term yixxing sānmèi 一行三昧 ("samāadhi of One Practice"; see Faure 1986b; on the term, see also Kobayashi 1961). The method of guānxin/kànxin was supposedly used by the monk Mahāyāna (who was closely associated with the Northern School) to defend the concept of "sudden enlightenment" at the famous Council of Lhasa, where Chinese and Indian monks debated the nature of enlightenment and ultimately defined it as "non-reflection and non-examination" (bù-sìbù-guān 不思不觀):

To turn the light of the mind towards the mind's source-that is contemplating the mind. This means that one does not reflect or examine whether conceptual signs are in movement or not. It also means to reflect on non-reflection. This is why the [Vimalakirti-nirdeśa] sūtra explains: "Non-examination is enlightenment." (P.4546, 135a; P.116, 161; cited in Gomez 1983: 103-104)

The term also appears in other texts of the early Chán School (e.g., the Dàshèng xinnxíng lùn 大乘心行論, P.3559, 28, l. 14; cf. Anderl 1995: 84 and 9o, fn. 412). However, the Council of Lhasa postdates our text by nearly half a century. It was convened in a time when Northern Chán was waning and Southern Chán was in the ascendancy. 
The discrimination of false thinking constitutes the capacity (i.e., essential feature) of the mind. ${ }^{44}$

As for "essence": if one realizes the essence then there is no further slandering. 45

Slander! 底利 [LMC: tiaj' li'] ${ }^{46}$ Slander! 嗄浪養 [LMC: sa: lay jiay']

All you sons of the Buddha! Do not commit slander!

All of you have the hindrance of karmic retribution.

Others hearing [your?] sound (i.e., words) [or: hearing the sound of others,] one will not be liberated by it. ${ }^{4}$

The tongue of three-inch [size] constitutes the direction towards extinction (i.e., disaster). ${ }^{48}$

[If the tongue] speaks long or talks short, ${ }^{49}$ it will [all] be an annoyance to the Mind King.

44 Xïliàng 心量 has several different meanings: synonymous with wéixin 唯心 (“mindonly"; Skr. citta-mātra according to the Lan்kāvatāra Sütra); a reference to nine kinds of consciousnesses that give rise to deluded thinking when coming into contact with physical or mental objects; and, more generally, the "domain/sphere of mind" (see Nakamura: $770 a)$. In the context of this passage, it probably refers to the human mind's typical way of functioning (i.e., the production of deluded thoughts).

45 According to Hirakawa, shít ̌̀ 識體 can refer to vijñāna ("consciousness"). It is actually a term used in Bodhiruci's translation of the Lankkāvatāra Sūtra (實無識體法, T.16, no. 671: $\left.567 b_{17}\right)$. This may explain why the term appears in our text. However, the meaning of the passage is unclear. (The Uyghur translation diverts significantly from the Chinese; see Chapter Three, this volume.) Tentatively, we interpret shàng 上 as a topic marker here ("concerning; as for").

$46 \quad$ These phonetically used characters do not fit the rhyme scheme.

47 The Chinese is somewhat problematic here and the translation is very tentative. If we consider täjiā 他家 as topicalization, then we could also translate in the following way: "If hearing the words of others, do not depend on them." The Uyghur makes more sense here: "If you hear speech from others, do not long for their words!" (see Chapter Three, this volume).

48 Again, the Uyghur is clearer here: "The speech organ of three inches is the only place of evil deeds." It is possible that mò 沒 has been used for mó 魔 (“demonic; evil”) here; the phonetic profile does not quite fit the regular LMC readings /mut/ vs. /mua/, but the final -t probably had already disappeared in the ninth/tenth-century Northwestern Medieval dialect (see Anderl and Osterkamp 2017). Another, albeit very unlikely, interpretation would be to take 作沒向 as an interrogative pronoun; 作沒 is regularly used for an interrogative corresponding to Modern Mandarin 怎麼 in late Táng texts and 作沒向 could be a rendering of 作沒生 (“how about; what about”, Modern Mandarin 怎麼樣). However, semantically, this does not fit the context here.

We decided to use a rather clumsy literal translation here in order to preserve the meta- 
[If] the Mind King is not understood, [then one will] speak short and long. When seeking a future path of rebirth one will receive bitter disaster.

羊良浪 [LMC:jiay liay lay $]^{50}$ Remove the obstacles! Having swept clean the hall one should make offerings.

\subsection{Strophe 4}

\section{拂粟質拂粟質}

第四：八識合六七。看心心本是禪室。法身身法智非一。五眼六通光慧

日。言下便悟實無密。密底利密魯留盧樓拂栗質

諸佛子莫放逸。無始已來居暗室。生死流轉不得出。只為愚迷障慧日。逸 粟密逸粟密娑訶直實。

5.6.1 Textual Annotations

- 拂粟質: repetition markers (P.2212, P.3099, P.3082). P.2204 and P.3099 attach this phrase to the last section and have 拂栗只; P.2212 has only two repetition markers (therefore: 拂栗拂粟只), distorting the phrase; P.3082 (茀慄只) has spaces above and below.

- 心: P.3082 has repetition markers.

- 法身身法智非一: the phrase is missing in P.3082.

- 光 (P.2212, P.3082): 廣 (P.2204, P.3099).

- 日: this character was originally missing in P.3099; it was added between 慧 and 言 in tiny size.

- 慧 (P.2204): 惠 (P.2212, P.3082); these two characters are routinely exchanged in Dūnhuáng manuscripts.

- 密: P.3082 has 蜜. The second 蜜 is indicated by a repetition marker.

- 底: P.3082 has the character (probably 多, which would make sense here).

- 密: the 蜜(?) after 利 is scratched out in P.3082.

- 留: 流 (P.3082); the two characters are phonetically identical.

- 拂栗質: 茀慄只 (P.3082).

- 逸栗密: repetition markers (P.2212). There may be something missing from this phrase.

- 訶: 耶 (P.2212).

phor of the "tongue." More freely, one could translate this section: "If one engages in any kind of [idle] talk ..." The "Mind King" refers to a person's cognitive functions (i.e., consciousness).

50 Alternatively: 王良量 LMC: yay liay liay. 
- 利 (P.2212): P.2204 and P.3099 have 領, which would also conform to the rhyme in the Northwestern Medieval dialect in which endings with and without a final nasal are not differentiated. ${ }^{51}$

- 質 (P.2212): 只 (P.2204, P.3099).

- 居 (P.2212): P.2204 and P.3099 have 歸居, breaking the 7+7+7 rhythm of the three successive phrases.

- 暗: 闇 (P.3082). P.3082 has the cursive form for 室.

- 愚迷 (P.2212, P.3082): P.2204 and P.3099 have an additional character (breaking the $7+7+7+7$ rhythm) between those two: 宾, 宣. We suspect this is a variant of 冥. 52

- 鄣: P.3082 is the only manuscript to use the form 障.

- 慧: 惠 (P.3082).

- 逸粟密: with repetition markers; P.3099 has 蜜 for 密. The phrasing is very different in P.3082: 逸多哩蜜訶斯耶真實.

\subsubsection{Translation}

拂栗質拂栗質

[LMC: fjyt(fut) sywk tsit fjyt(fut) sywk tsit $]^{53}$

Fourthly, the eight vijñana (consciousnesses) encompass the sixth and the seventh [consciousnesses].

Contemplating the mind, the origin of the mind is the meditation chamber. The dharma-kāya (dharma-body; i.e., the absolute truth) and kāya-dharma (dharma of the body; i.e., the self), their wisdom is not identical. ${ }^{54}$

$5^{1} \quad$ See Anderl and Osterkamp 2017.

$5^{2}$ Cf. the characters listed in Huáng Zhèng 2005: 278. 愚冥 is listed as a term in Hirakawa and Kōsetsu Bukkyōgo daijiten.

53 Alternatively: 茀憟只茀憟只 (LMC: /fjyt sywk tşi fjyt sywk tsii) (last syllable without final stop!). This indicates that the rùshèng might have already disappeared in the northern and northwestern regions by this time, and that 質 and 只 had the same rhyme.

54 The Uyghur makes more sense here: "[There are] dharma-body and dharma wisdom, but again they are not one" (see Chapter Three, this volume). However, the Uyghur translation corresponds to the Chinese 法身法智非一 and ignores the second 身. For the term shēnfă 身法, see Hirakawa: 1129. According to Nakamura: 773d, shēnfă was used by Ān Shìgāo to translate Skr. ātman ("self"). Anyway, the passage seems to be contrastiveabsolute truth/wisdom as compared to mundane truth/wisdom. Perhaps, in the Chinese, 智 could also be interpreted as 知 (“know, they are not one!"), since these two characters are routinely exchanged in Dūnhuáng manuscripts. Kobayashi translates the passage as follows: hosshin to shinhō, chi wa itsuni arazu 法身と心法, 智は一に非ず (“Dharmabody and dharma of mind are in knowledge not one"; corresponding to 法身心法智非 一). As such, he interprets the second 身 as a substitution for 心. This is feasible, since 
The Five Eyes ${ }^{55}$ and the Six Penetrations ${ }^{56}$ are the bright sun of wisdom. Hearing these words one is then enlightened, and truly there is nothing secret $^{57}$

Secret! [LMC: mit]! 底利 [LMC: tiaj' lih ${ }^{\mathrm{h}}$ ] Secret! [LMC: mit] All you sons of the Buddha, don't be negligent!

Since the beginningless past you have dwelled in a dark room.

Birth and death follow one after the other, and you have not been able to get out [of samsāra].

[It is] only because of foolish illusions, [that we] block the sun of wisdom.58

逸粟密逸粟密 [LMC: jit suawk] Secret!—Svāhā! True Reality!59

\section{$5 \cdot 7 \quad$ Strophe 5}

曉燎曜曉燎曜

第五：實相門中照。一切名利妄呼召。如已等息貌非貌。非因非果無嗔

㗛。性上看性妙中妙。要底利要魯留盧樓曉燎曜

諸佛子莫瞋㗛。憂悲瞋㗛是障道。於此道門無瞋㗛。澄心須看內外照。眼

中有鹥須摩曜。銅鏡不磨不中照。

遙燎料作好。娑訶耶莫惱。

in Northwestern Medieval Chinese the readings of the two characters are phonetically very similar. For example, several of these substitutions occur in the Dūnhuáng version of the Platform Scripture (心 < > 身; 心 < > 深; see Dèng and Róng 1999: 315, n. 1; 421, n. 4; 426, n. 11). Another reading is suggested by the scholar Huáng Qīngpíng 黃青萍 (personal communication), who reads 法身智 as three items commented on by 非一 (“As for the dharma-body, dharma, body, and wisdom are not one").

55 The Five Eyes (Skr. pañca cakșūmṣsi) are: human eye; divine eye; wisdom eye; dharma eye; and Buddha eye (cf. FDC, Vol. 2: 1151c-1152a).

$5^{6}$ The Six Penetrations (Skr. șaḍabhijñāa) are those of: spiritual fulfillment; divine ear; knowledge of others' thoughts; knowledge of one's own and others' lifespans; divine eye; and full knowledge of and testimony to the cessation of rebirth (cf. FDC, Vol. 2: 1292c-1293a).

Yán-xià biàn wù 言下便悟 is frequently encountered in Chán Buddhist recorded sayings (lit. "under these words" > "based on these words, triggered/caused by these words") is used in reference to words uttered by the master that cause awakening in the student (early examples in the Shénhui yǔlù and the Platform Scripture).

$5^{8}$ There are only three verses instead of four in this strophe.

59 Alternatively: 逸多哩密 LMC jit ta li’ mit 斯耶 (Svāhā!) True Reality! 


\subsubsection{Textual Annotations}

- This section starts with a new column in P.2212.

- 曉燎曜: repetition markers (P.2212).P.2204 and P.3099 have 曉了曜; P.22O4 is attached to the previous section, and P.3099 has spaces above and below. The repetition marker after 了 is missing in P.2204. P.3082 has 失(?)了曜 (with repetition markers, and spaces above and below).

- 利: P.3082 has 色. According to Dünhuáng gēcí, 名利 is a mistake for 名字. However, the Uyghur translation supports the reading 色 ("name and form").

- 息: P.3082 has (普?; if it were not for the lower element, one could also think about 苦), which certainly does not look like a variant of 息. The variant also resembles 昔.

- 貌: P.2212, P.2204, and P.3099 have the current variants 皃舁, and respectively. P.3082 has

- 貌非貌 (P.2212, P.3099, P.3082): only 貌 in P.2204 (> 貌非因非果).

- 因 (P.2212): here written with the "standard" 因 instead of the previously used 曰, current in Dūnhuáng manuscripts (also used in P.3082).

- 㗛: there is a dot on the right side 笭. (P.2212).

- 利: it is difficult to decipher the character in P.2212, but it seems to be 利; P.2204 and P.3099 have 裏.

- 燎: the T. editors read 撩 in P.2212, which is incorrect; all of the manuscripts have 燎.

- 道門 (P.2212): 門中 (P.2204, P.3082).

- 瞋 (P.2204, P.3309): 嗔 (P.2212, P.3082).

- 看 ...: the text is preserved in S.4583v from here onwards.

- 㗛: 笑, using a phonetic loan 桨

- 摩 (P.2212): 磨 (P.2204, P.3099, P.3082, S.4583v).

- 曜 (P.2212, P.2204, P.3099; LMC: jiaw); 燿 (S.4583v; LMC: jiaw).

- 燎 (P.2204, P.3099): 僚 (P.2212; LMC: liaw).

- 遙燎料作好乷訶耶莫惱: there is a major diversion from this phrase onwards in S.4583v, integrating elements that appear in Strophe 3 in the other manuscripts (羊良浪併當淨掃堂中須供養). This is actually not arbitrary since 掃 does not fit the rhyme scheme (-ang) of this section; S.4583v has integrated it in the -ao group section in which the phonetic profile of 掃 fits much more neatly. The phrase in S.4583v is: 遙遼了若掃薩訶也(?)淨掃 (“if sweeping ... sweep [it] clean”). P.3082 also has a very different reading: 僚僚 (indicated by repetition marker) (?) (?)掃斯訶耶淨掃. 遙 LMC: jiaw; 燎 LMC: liaw; 料 LMC: lew; 遼 LMC: liaw; 了 LMC: liaw'; 掃 LMC: saw'. 


\subsubsection{Translation}

\section{曉燎曜曉燎曜}

[LMC: jiaw liaw jiaw jiaw liaw jiaw]

Fifthly, True Reality shines in this gate (i.e., teaching). All names and forms are false appellations. ${ }^{60}$ In this kind of consciousness (mind) ${ }^{61}$ form is not form. There is no cause and there is no effect; do not laugh at this with scorn! As for Nature, view Nature as the utmost marvel (lit. "marvel among marvels")!

要(> 妙) Marvel! [LMC: miaw'] 底利要(> 妙) [LMC: tiaj' li’] Marvel! 魯留盧樓 曉燎曜 [LMC: luă liw luă ləw jiaw liaw jiaw]

All you sons of the Buddha, don't be scornful and ridicule others!

Grief, scorn, and ridicule with anger are hindering the [realization of the] Way.

In this method of the Way there is neither scorn nor ridicule.

In order to illuminate the mind ${ }^{62}$ one should contemplate the inside and illuminate the outside.

If a hair comes into the eye, one should rub it [i.e., the eye] clean. If the bronze mirror is not polished, nothing can be reflected therein. ${ }^{63}$

遙燎料 [LMC: jiaw liaw lew] Do good! (i.e., perform good deeds!) Svāha-ya! Do not have vexations!

\subsection{Strophe 6}

\section{按賴畔按賴畔}

第六：心離禪門觀。不來不去無崖畔。覺上看覺除定亂。佛與眾生同體 段。本原清淨摩垢散。歎底利歎魯留盧樓按賴畔

6o Cf. hūzhào jiămíng 呼召假名 (“an agreed-upon appellation”; Skr. āhvānāya saṃketah; DDB).

61 The Chinese is problematic here, and 息 seems to have been interpreted as 心 in the Uyghur translation (see Chapter Six, this volume). In Northwestern Medieval Chinese, 息 was sometimes used for 心 (no difference between endings with and without nasal). So it could also refer to 識 ("consciousness, mind"); there are examples of this in the Platform Scripture. In our translation, we opt for this interpretation. Originally, the passage may have read: 如已息心 (“If one is calming the mind like this [then form is no-form]").

62 On chéngxin 澄心, see Nakamura: 967b.

63 This passage recalls the famous pairs of gäthas on the mirror-mind attributed to Shénhuì and Huinéng, as conveyed in the Platform Scripture (cf. T.48, no. 2007:337c). 
諸佛子莫慢看。道上大有羅刹喚。愚人來去常敖絆。染著色塵心僚亂。行 住坐臥無體段。在於眾中漫叫喚。得他勸諫即橛難。耶羅邏茶灌。乷訶 耶鈍漢。

\subsubsection{Textual Annotations}

- Space of approximately five characters before this paragraph in P.2212; spaces of one character above and one below in P.3099; spaces above and below in P.3082.

- 按賴畔: repetition markers (P.2212);P.3099 lacks the repetition marker of the middle character. In P.2204 and P.3099, the phrase is 頞崖畔, and in P.2204 it is attached to the previous section (this time "correctly," with three repetition markers). S.4583v does not have two identical phrases but rather: 吐 㸊崖頞崖畔. P.3082 has repetition markers and the phrase 案崖畔. 按: LMC

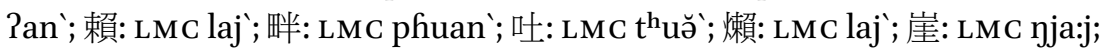
頞: LMC Pan'.

- 離 (P.2212, P.2204): 裏 (S.4583v, P.3099, P.3082).

- 覺: variant 䡒 (P.2212); P.2204 uses two rather different variants in the same line, 觜 and 露 (the latter form also appears in the next section). It is inter-

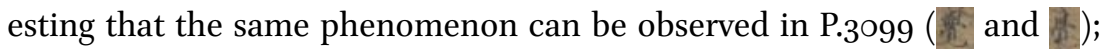
this shows the close interdependence of the two manuscripts. of the last character of the text in P.2204. S.4583v has $\mathrm{V}$. P.3082 has a very different reading of the phrase 覺上看覺除定亂: 不出不入無定亂 (“As for realization: if one views realization then one gets rid of both concentration and confusion; no coming out and no entering, there is neither concentration nor confusion").

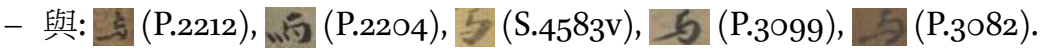

- 佛: P.2212 and P.3099 have the correct 佛與眾生同體段 (“Buddha and sentient beings having the same characteristics"). The copying mistake 佛子 與眾生 ("sons of the Buddha and sentient beings") in P.2204 was probably triggered by the frequent occurrence of 佛子 in the manuscripts. As a minor observation, P.2204 consequently uses 佛 for "Buddha," whereas P.2201, P.3099, P.3082, and S.4583v all prefer 仏.

- 段: P.3082 uses an interesting variant here: ${ }^{1}{ }^{1}{ }^{64}$

- 原 (P.2212, P.3082): 元 (P.2204, P.3099), 源 (S.4583v).

- 摩 (P.2212): 磨 (P.2204, P.3099), 魔 (S.4583v, P.3082).

- 歎: P.3082 has a repetition marker after 散(?) instead of 歡 (> 散散, possibly),

64 This is very similar to one that Huáng Zhèng 2005: 93 found in the Wǔž̌xū biànwén 伍子 胥變文 (S.328). 
but we are unsure whether refers to 散 or 歡. ${ }^{65}$ The other manuscripts are problematic here, since 散 should be repeated at the beginning of the phonetic phrase; therefore, the line should probably read: 本原清淨摩垢散。散 底利散(歏).

- 利 (P.2212, P.22O4, P.3082; LMC/li'/): 礼 (S.4583v; LMC /liaj/); 領 (P.3099); in the Northwestern Medieval dialect there is no difference in pronunciation between syllables with and without $-\mathrm{ng} / \mathrm{y} /$, as such 利 and 領 are homophonous. The entire phrase in P.3082 is: 多利散魯流盧樓案崖畔 (多 利 maybe corresponds to tari or tali in Sanskrit phonetics).

- 按 (P.2204): 桉 (P.2212); 頞崖 (S.4583v and P.3099; as such, repeating the "rhyme trigger phrase" from the beginning). There is no space before 諸弟 子 in P.2212.

- 慢: the T. editors have an erroneous reading here: 楞. P.2212 and S.4583v both have 滑, which is a variant of 漫; 66 P.2204 has 愣 (愣); P.3099 has 情 (慢); P.3082 has

- 看道: P.2212 has 道看 with a marker for reversed order on the right side. P.3082 has kăn 偘 instead of 看. 偘 is a variant form of 㑆. We have found no precedent for using 偘 as phonetic loan for 看, although the LMC readings are similar: 看 $k \bar{a} n \mathrm{k}^{\mathrm{h}}$ an, 偘 $k a ̆ n \mathrm{k}^{\mathrm{h}}$ an', differing only with respect to the tone.

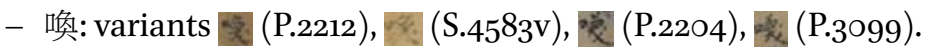

- 愚人來去常繫絆染著色塵心僚亂行住坐臥無體段: here, the text of P.3082 is much shorter: 愚人來時(?)常結伴. ${ }^{67}$

- 常 (P.2212, P.2204, P.3099): 相(?) (S.4583v).

- 染 (P.2212): P.2204 has 杂, which, according to the tenth-century Lóngkān shǒujing 龍弇手鏡 dictionary, is a variant of 雜. Often, 杂 is also associated with 朵 (although that does not apply here). P.3099 has the variant

- 僚 (P.2212, P.2204, P.3099): 遼 (S.4583v).

- 於: P.3099 uses the semi-cursive $\mathbb{X}^{\text {? }}$.

- 眾中 (P.2212, P.2204, P.3099): 眾生 (S.4583v).

- 漫: 浐 (P.2212). S. $4583 v$ has the character 执, possibly referring to 忶, which is a variant of hún 愧. On 忶, the Jíyún 集韻 states: 心悶也 ("the mind is depressed") and 心迷也 (“the mind is confused"). As such, the meaning is rather close to that of 漫. P.3099 has

- 即橛: 須掘(?) (P.3082).

- 耶: 夜 (P.3082).

- 邏 (P.2212, P.2204, P.3099): 囉 (S.4583v).

65 Although, after a comparison with forms listed in Huáng Zhèng 2005: 348, we favor 散.

66 On this character form, see Huáng Zhèng 2005: 264.

67 On jié bàn 結伴, see Zengaku daijiten: $274 \mathrm{c}$. 
- 灌 (P.2212, P.2204, P.3099): 觀(?) (S.4583v, P.3082).

- 娑: 思 (P.3082).

- 耶 (P.2212, P.2204, P.3099): 也 (S.4583v), 夜 (P.3082).

- 鈍: (P.3082). After 鈍漢, P.3082 has the following character: Originally, the copyist probably added the character 勃 before he realized that it is part of the phonetic phrase of the next section. Rather than scratching it out (which must have been esthetically unappealing for a copyist who in this case was obviously concerned with proper arrangement and calligraphy), he added a dotted circle and thereby "deleted" the character. $E$ is a variant of tún 屯. 屯 (LMC thun) has a similar phonetic profile to dùn (LMC thun') and should be considered as phonetic loan here.

\subsubsection{Translation}

\section{按賴畔按賴畔}

[LMC: ?an' laj' phuan' Pan' laj' phuan']

Number Six, the Chán gate (i.e., method) of contemplation being apart from thought (i.e., leaving the sphere of thought).

There is no coming or going, and there are no boundaries.

As for realization: viewing realization, both concentration (samāalhi $)$ and confusion are eliminated.

As for the Buddha and the sentient beings, they have the same features. The origin is clear and pure: rubbing [it clean], the filth is dispersing.

歎/歡(>散) Disperse! 底利 [LMC tiaj' li'] 歎/歡(>散) Disperse! 魯留盧樓按賴 畔 [LMC: luă liw luă ləw Pan` laj’ phuan’]

All you sons of the Buddha! Don't be careless in contemplation! Although the Way is lofty, there are still rakșas (i.e., demons) who may appear.

Foolish people come and go, constantly shackled by [their own] fetters.

Polluted (i.e., impure) they grasp after form objects and their minds are thrown into confusion.

In all activities such as walking, standing, sitting, and lying down, there are not any [distinguishing] features.

In [the realm of] the sentient beings, there is boundless wailing. ${ }^{68}$ If one manages to remonstrate (i.e., convince them of the correct way), then [they] will get rid of all difficulties.

68 In Buddhist texts, jiàohuàn 叫喚 ('to wail; to cry out;' originally translating Skt. raurava) is often used metaphorically for the suffering in hell. 
耶羅邏茶灌(?) [LMC: jia la la’ trha: guan] Svāha-ya! 鈍漢 Dull fellows [LMC xan']!

\section{$5 \cdot 9 \quad$ Strophe 7}

\section{普路喻普路喻}

第七：圓明大慧悟。四門十八離名數。生滅妙有懸 $(=$ 玄 $)$ 通度。三界大師實 難遇。生死涅槃不合渡。愛河逆上不留住。即心非心魔自去。去底利去 魯留盧樓普路喻

諸佛子)〉常覺悟。一念淨心無染污。一切魔軍自〈pb:T_T85n2779_0536c)然去。 閭閭屡專注。娑訶耶大悟。

\subsubsection{Textual Annotations}

- 普路喻: repetition markers (P.2212, P.3099). P.2204 has no repetition markers, and the phrase has empty spaces above and below. S.4583v uses repetition markers for the phrase 拂魯與. P.3082 has the phrase 勃路与(與), spaces above and below, and uses repetition markers. 勃 LMC: phut; 普 LMC: $\mathrm{p}^{\mathrm{h}} \mathrm{u}$ ` (> $\mathrm{p}^{\mathrm{h} u}$ ); 拂 LMC: fjut; 路 LMC: luă (> lu'); 喻 LMC: jyă (> y').

- 圓: 無 (P.3082).

- 四門十八離名數生滅妙有懸通度: P.3082 has a much shorter version: 四生 妙有玄通度.

- 慧 (P.2212, P.2204, P.3099): 惠 (S.4583v, P.3082).

- 生滅妙 (P.2204, P.3099): 生妙 (P.2212).

- 懸 (P.2212, P.2204, P.3099): phonetic loan for 玄 (S.4583v); these two characters are often exchanged in Dūnhuáng texts.

- 師 (P.2204): variant 117 in P.2212.

- 遇: 愚 (P.3082).

- 生死涅槃不合渡: S. $45^{8} 3$ diverts here (integrating elements from other passages): 生心動念勿令住 ("generating the mind and stirring up thoughts, do not let them reside!"). In P.3082, the passage differs even more: 生死涅槃 不合渡愛河逆上不留住即心非心魔自去 is abbreviated to 則心非心魔自去 ("then the mind is not the mind and the demons disperse by themselves").

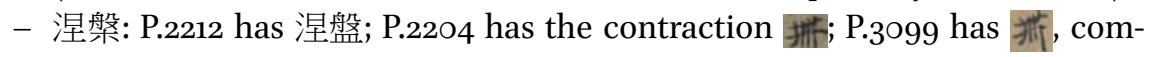
monly used in Dūnhuáng manuscripts.

- 合度: P.2204 has 度合 (“corrected" by a reversal marker).

一 逆: variant 羊 in P.2212; 洋 in P.3099.

- 上 (P.2212, P.2204, P.3099): 順 (S.4583v).

- 留 (P.2212, P.2204, P.3099): 流 (S.4583v).

- 去: replaced by repetition marker in S.4583v.

- 底: 多 (P.3082).

- 利 (P.2212): 裏 in P.2204 and P.3099; 礼 in S.4583v; missing in P.3082. 
- 留: 流 (P.3082).

- 普路喻 (P.2212, P.2204, P.3099): 拂魯與 (S.4583v); 勃路与 (P.3082).

- $\rangle$... $\langle$ marks a passage that is partly preserved in the fragment дхн $424 \mathrm{r}$ (formerly: Дx492); the page is torn in the middle (see the Appendix).

- 覺悟: P.3082 has a reversal marker between the two characters (悟覺?).

- 一念淨心無染污 (P.2212, P.2204, P.3099, дХH 424r): S.4583v has 淨心住立(?) 無染污 ("If the pure mind is firmly established then there are no impurities”). For the phrase 一念淨心無染污一切魔軍自然去, P.3082 has: 淨心 住立無染惡切魔(repetition marker)軍自然去 (“if the pure mind is firmly established then there is no pollution, and the army of evil demons will disperse by itself").

- 閭: replaced by a repetition marker in P.2204, P.3099, and дхн 424r.

- 閭閭屢專注 (P.2212, P.2204, P.3099): S.4583v is very different here: 依問呂專 住. For 問問屢專注娑訶耶大悟, P.3082 has the following: 呂( ? ) 呂專住思訶 夜大悟. 誾/呂 LMC: liă’/ lyă’ (> ly) 依 LMC: ?i (> ji) 屢 LMC: lyă’ (> ly).

- 耶 (P.2212, P.2204, P.3099, дХн 424r [Е): 也(S.4583v).

- 大 (P.2212, P.2204, P.3099): S.4583v has 待, which is very strange ("awaiting enlightenment" instead of "greatly enlightened").

\subsubsection{Translation}

普路喻普路喻

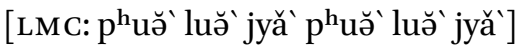

Seventh, concerning the awakening to the complete and bright great prajña The Four Methods and 18 [kinds of practice] transcend the numbering ${ }^{69}$ [of doctrines, etc.]. Those [caught in the] marvelous existence [of the circle of] birth and death are mysteriously liberated. ${ }^{70}$

Within the Three Worlds, a great master is truly difficult to encounter.

Samsāra and nirvāna, there is no need to cross over to. ${ }^{71}$

69 On the term mingshù 名數, see Nakamura: 1300c (DDB: "Name and number. A numbered term, such as 'three realms, 'ninth stage,' etc."). This could also be interpreted as an exhortation not to become attached to a particular doctrine (as discussed in Abidharma literature), but rather to find a good teacher for instruction.

70 Miàoyóu 妙有 ("marvelously existing") is sometimes enumerated as one of the three kinds of existence (sānzhǒng yǒu 三種有): i.e., shíyǒu 實有 (“really existing”), jiăyǒu 假 有 (“provisionally existing”), and miàoyǒu (“marvelously existing”). The latter often refers to the "emptiness-aspect" of all things (zhēnkōng miàoyǒu 真空妙有). 四生妙有玄通度 (P.3082): "The marvelous existence of the four kinds of beings is mysteriously liberated [?]."

71 The different versions of this passage in the various manuscripts suggest that the text is particularly problematic here. 
The river of affections runs counter to the supreme [truth]; do not dwell in it! If this mind [therefore] is without thought, the army of Māra (demons) will depart by itself.

Depart! 底利 [LMC: tiaj' li'] Depart! 魯留盧樓普路喻 [LMC: luă liw luă ləw p $p^{\text {h } u a ̆ ’}$ luă’/ jyă']

All you sons of the Buddha! If you have a pure mind throughout every single thought (or: one-pointedly pure mind), there will be no impurities, and the entire army of Māra will depart by itself.

閭閭屢 [LMC: lyă lyă lyă] Concentrate! (zhuānzhù 專注) Svāhā-ya! Great Awakening!

\subsection{Strophe 8}

嗄略藥嗄略藥

第八：禪門絕針酌。不高不下無樓閣。不出不入無城墎。是想顯聲即初 學。生心《動念勿令著。久坐用功作非作。無樂可樂是常樂。慧燈一照 三千墎。定水常清八萬鎡。十方諸佛同開覺。覺底利博魯留盧樓嗄略藥 諸佛子自在作莫制約。四維上下不可度。住寂涅槃同門廓。甚安樂無著。 娑訶耶等覺。

\subsubsection{Textual Annotations}

- 嗄略藥: repetition markers (P.2212): P.2204 and P.3099 have 復罟藥 with three repetition markers; the phrase is separated by spaces above and below. S.4583 (also using three repetition markers) has a different first character

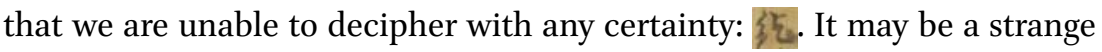
cursive form of 復, although the Zhōngguó căoshū dàzidiǎn 中國草書大字典 does not contain any similar form of this character. Osterkamp suggests that it may be a cursive form of 紀. P.3082 also singles out the phonetic phrase with spaces above and below, using repetition markers. It reads: 訶洛樂. 略 (LMC: liak), 藥 (LMC: jiak).

- 針 (P.2212, P.2204, P.3099, дXH 424r): 㱚 (S.4583v). The form looks like 期 (one of its meanings being "to cut"); or it could be 湛. P.3082 has 占. It might also be interpreted as a cursive form of 㽎, a reading that would fit well within the context. ${ }^{72}$

72 Suggestion by Sven Osterkamp. 
- 酌 (P.2212, P.2204, P.3099, S.4583v, ZXH 424r): 勺 (P.3082).

- 墎 (P.2212): 郭 (P.2204, P.3099, S.4583v, P.3082); the same in the occurrence below.

- 是想顯聲即初學 (P.2204, S.2212, P.3099): S.4583v is very different as it has 視相見聲, but this actually makes more sense than the other three manuscripts: "gazing at form/features, seeing the sound." P.3082 has the phrase: 是相聲最初學.

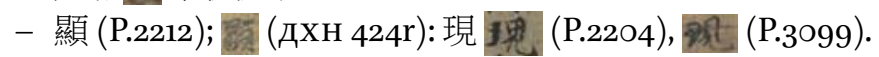

- 學(P.2212, S.4583v, ДXH 424r):齐 (P.2204); 苶(P.3099): these are all “variants of the variant" form 享.

- 非 (P.2212, P.2204, P.3099): 不 (S.4583v, P.3082).

- 可樂 (P.2212, P.3099, S.4583v, P.3082): missing in P.2204.

- 慧 (P.2212, P.2204, P.3099): 惠 (S.4583v, P.3082).

- 鑠(P.2212, P.2204, P.3099, S.4583v):扚(?) P (P.3082); 鑠 is used phonetically (abbreviated: śe) for Skr. kleśa ("afflictions").

- 覺: indicated by repetition markers in P.2212, P.2204, P.3099, S.4583v.

- 底 (P.2212, P.2204, P.3099): 得 (S.4583v).

- 利 (P.2212): 裏 in P.2204, P.3099, S.4583v.

- 嗄 (P.2212): 復 (P.2204, P.3099); 行 (S.4583v).

- 上: because of severe paper damage, in P.3099 only 廓甚安樂無 of the last part is extant. Originally, this manuscript had a colophon with the date of the copy. However, only a few characters are still recognizable (... 九月栽( ?)日

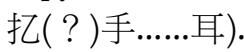

- 槃: 盤 (S.4583v).

- 安: unrecognizable in P.2212 (torn paper).

- 樂: in P.2212, 樂 is repeated; there is also a repetition marker in S.4583v.

- 門廓 (P.2212, P.2204): 開覺 (“to awaken”) in S.4583v.

- 娑(P.2212, P.2204): 薩 (S.4583v).

- 耶 (P.2212, P.2204): 也 (S.4583v).

- 十方諸佛同開覺覺底利博魯留盧樓嗄略藥諸佛子自在作莫制約四維上下 不可度住寂涅槃同門廓甚安樂無著娑訶耶等覺: P.3082 differs radically: 十 方諸佛同開廓甚安樂(repetition marker)無看（著？）思訶夜等覺. 思 should probably be read as sāi here (LMC: saj), with similar phonetics as compared to $s u \bar{o}$ 娑 (LMC: sa). 耶 (LMC: jia); 夜 (LMC: jia'); 訶 (LMC: Xa); 思訶耶 > Skr. svāhā-ya. 


\subsubsection{Translation \\ 嗄( $>$ 復)略藥嗄 $(>$ 復)略藥}

Number Eight: The method of Chán cuts off random speculation. ${ }^{73}$

Neither high nor low, there are no multi-storied buildings. There is neither leaving nor entering, and there is no city. ${ }^{74}$

This thought manifested in sound (?), this is the initial learning (or: [for] beginning students). ${ }^{75}$

When generating the mind and giving rise to thoughts, don't let [yourself] attach [to them]!

[When] making the effort to sit long time [in meditation], then action will be no-action.

There is no joy that can be enjoyed; this is [called] "eternal joy."

The lamp of wisdom at once illuminates the 3,000 worlds. ${ }^{76}$

The water of sam $\bar{a} d h \bar{\imath}^{77}$ is constantly purifying the 8 ,ooo kleśas. ${ }^{78}$

All the buddhas of the Ten Directions achieve enlightenment at the same time.

Enlightenment 底利 [LMC: tiaj' li'] Extensive!

All you sons of the Buddha! Remain self-so and do not [artificially] restrain [yourselves]!

73 Zhènzhuó 㽎酌 has a specific meaning in Chán texts. Its original meaning is "to deliberate, consider." In the Buddhist context, it can also mean "to serve alms food" (Meisig and Meisig 2012: 116). In their translation of the Línji lù, Sasaki and Kirchner 2009: 139 translate it as "random speculation." The term is also frequently used in the JDCDL (Christian Wittern, in a draft version of a German translation of the JDCDL, translates it as "irrige Denkweise" = "deluded way of thinking").

74 This may be a reference to the famous illusionary city of the Lotus Sūtra, a very popular metaphor for upāya ("skillful means"). One passage in this sūtra contains both 城郭 and 樓閣 (T.9, no. 264: 161c 化作大城郭 莊嚴諸舍宅 周匝有園林 渠流及浴池 重 門高樓閣 男女皆充滿). Karashima 2013: 250 translates 樓閣 as “a lofty building, a storeyed building."

75 This passage possibly should be modified according to the Uyghur translation, which has "sign; feature." 相 and 想 are often exchanged in Dūnhuáng texts: “These signs/features appearing as sound [for] the new student."

76 郭 should probably be interpreted as homophonous to 國. The expression 三千國 is frequently encountered in sūtra literature, corresponding to the Skr. tri-sāhasra.

77 For more on the expression "water of samādhī" see Chapter Three, this volume.

78 鈢 is used phonetically here for śa, as an abbreviation for kleśa (cf. 僧吉隸䤼; Skr. san்kleśa). 
[Those with] the Four Bonds (Skr. bandhanas), ${ }^{79}$ [whether they are] of high or low status, cannot be liberated.

When residing in nirvānic extinction, one achieves awakening together. ${ }^{80}$ In utter quiet bliss there is no attachment.

Svāhă! May all be enlightened!

The so-called Siddham Song is remarkable for several reasons. Written in the context of Chán Buddhism, it reflects early Chán thought, and especially the lineage associated with the Lankkāvatāra Sütra, in addition to integrating terms that are typical of the early phase of the movement. As a special feature, the preface not only connects the sūtra, its translator Gunabhadra, and Bodhidharma (the founding figure of Chán), but also associates the text with the famous translator Kumārajīva, who is credited with introducing the Siddham material to China. Unfortunately, the entire text of the Töngyùn, which is attributed to Kumārajīva, is not preserved. However, sections of the preface are extant among the Dūnhuáng manuscripts, and these give us an insight into the importance attributed to the sounds of the Indian alphabet. Indeed, they are described as highly efficacious soteriological tools.

The preface to the Siddham Song also mentions the monk Dìnghuì, who is credited with composing the text. It explains its purpose of transforming the mysterious and difficult contents of the Lañkāvatāra Sütra into a short message that could be both "performed" and understood by the common people. The result is an interesting mix of phrases including doctrinal terms and statements, in addition to warnings, prohibitions, and exhortations. The various sections are connected by "trigger phrases" (which were probably designed to stick in the mind of the listener/reader), accompanied by characters that clearly have no semantic reference. Most significant is the structure of the text, which obviously had to be sung in a series of strophes. Its "didactic" build-up alternates between prescriptive sections and proscriptive sections, also illustrating the negative consequences of transgressions. It includes a high percentage of phonetically used characters, reflecting both "Chinese" and "Sanskrit" sounds,

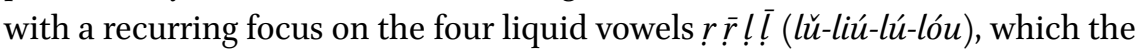

79 The four bonds are: desire, wealth, ignorance, and distorted views. Cf. $F D C$, Vol. 2: 1827 b.

$80 \quad$ Following S.4583v (同開覺); the other manuscripts pose severe textual problems here. 
Chinese audience may well have interpreted as extremely exotic and mystical. The rhyme patterns include both semantically and phonetically used characters, and nearly 25 percent of all of the characters rhyme (each strophe uses a different rhyme). Here, the intention was probably to increase the mnemonic and "musical" aspects of the text.

Finally, the numerous copies of the Siddham Song neatly illustrate that early Chán thought and doctrine remained highly relevant in the northwestern regions until at least the tenth century, and probably much later.

\section{Appendix}

Here, with the kind permission of the Institute of Oriental Manuscripts at the Russian Academy of Sciences, we reproduce a manuscript fragment of the Siddham Song that is not readily accessible at IDP. The manuscript number is дXH 424 (formerly Дх492). The fragment is a folio from a booklet with folded pages (i.e., each leaflet comprised two pages). The leaflet is torn, and the upper part is missing. However, parts of the introduction and parts of Strophe 8 of the Siddham Song are extant on the recto side. Based on an estimate of the approximate number of characters that could fit on one page, the extant pages must be page 2 and (probably) page 15 of the text. (Hence, the whole booklet probably contained about sixteen folded pages, with the leaflets stitched together in the middle.)

Dūnhuáng texts in booklet (rather than scroll) form were practical because there was no need to unroll them and it was much more easy to take them on travels. In contrast to many of the scrolls discovered at Dūnhuáng, booklets were often produced locally rather than imported from the central regions. This may be interpreted as an indication that our text enjoyed local popularity and was frequently copied in the Dūnhuáng area. Most of the extant booklets among the Dūnhuáng manuscripts can be dated to the late Táng/Five Dynasties period.

The text was probably written on only the recto sides of the leaflets, as the extant verso side contains no content related to the text. Indeed, the phrases we find on the verso cannot be associated with any extant Chinese Buddhist text. They might be interpreted as disconnected scribbles, or a random collection of Buddhist terms and phrases. On the left side of the verso, there is a drawing of an animal or more likely a demon. This material suggests that the Siddham Song was written exclusively on the rectos, with the versos left blank. As the extant passages are symmetrically "remote" from each other (i.e., the second page of the preface and the second to last page of the final strophe), the folio 


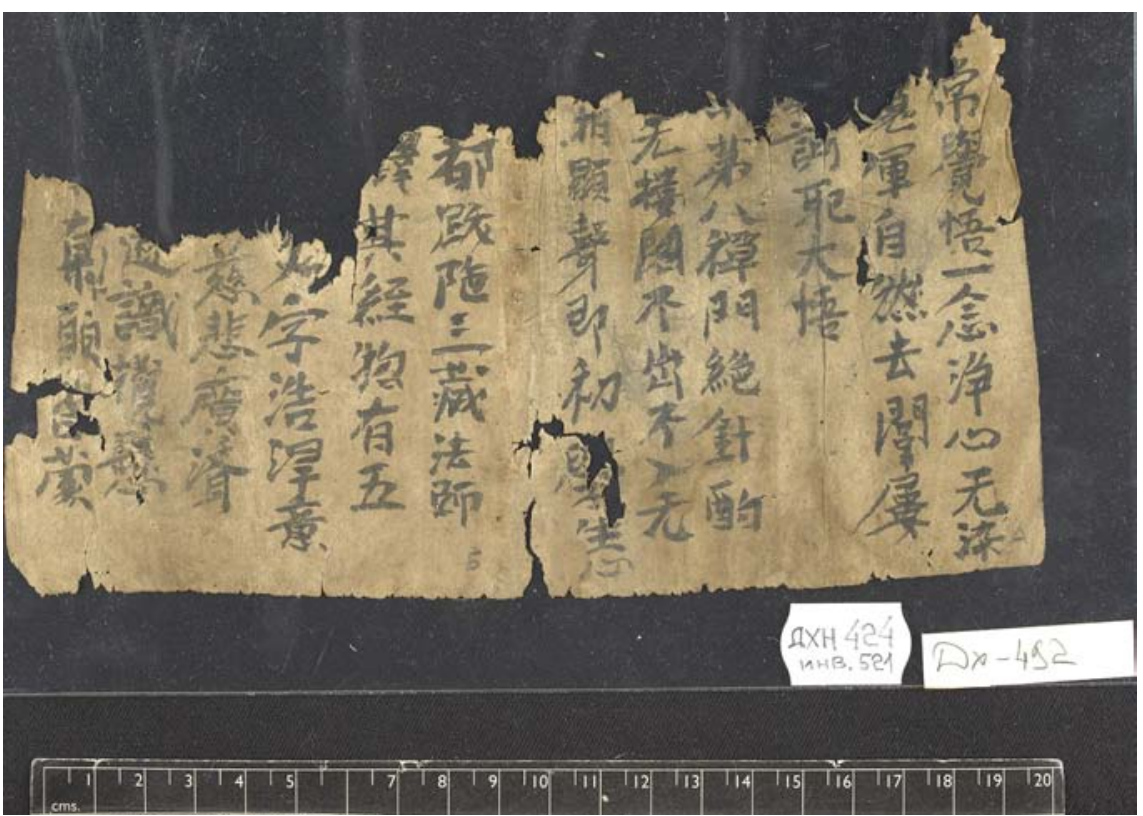

FIGURE 2.2 ДХН 424 (formerly ДХ492), recto REPRODUCED WITH THE KIND PERMISSION OF THE INSTITUTE OF ORIENTAL MANUSCRIPTS, RUSSIAN ACADEMY OF SCIENCES

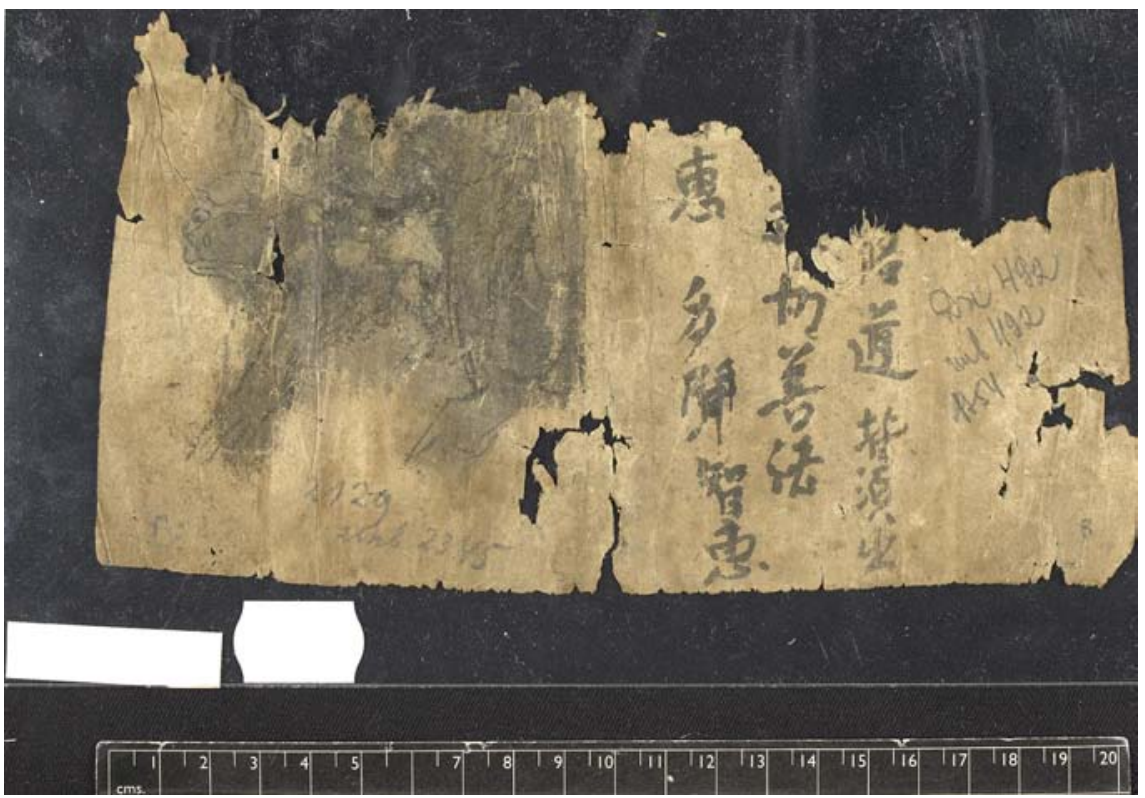

FIGURE 2.3 ДХН 424 (formerly Дх492), verso REPRODUCED WITH THE KIND PERMISSION OF THE INSTITUTE OF ORIENTAL MANUSCRIPTS, RUSSIAN ACADEMY OF SCIENCES 
must have been wrapped around other pages (atypical for booklets in butterfly format, in which double pages are usually arranged next to each other). ${ }^{81}$

Right part of the recto side, "page 2 " of the text: ${ }^{2}$

\section{來至東都跋陀三藏法師 \\ 奉諮翻譯其經總有五 \\ 卷合成一部文字浩汗意 \\ 義難知和上慈悲廣濟 \\ 郡品通經問道識攬玄 \\ 宗窮達本原皆蒙}

Left part of the recto side, probably the second to last page of the text (“page 15"):

\section{諸佛子常覺悟一念淨心無染 \\ 污一切魔軍自然去闆(閭)屢 \\ 專注娑訶耶大悟 \\ 嗄略藥嗄略藥第八禪門絕針酌 \\ 不高不下無樓閣不出不入無 \\ 城墎是想顯聲即初學生心}

Right part of the verso side:

\section{... 道皆須出 \\ …协(=協)善法 \\ ... 惠多聞智惠}

\section{References}

\section{Manuscripts, Primary Sources, and Collections}

Dà-Táng Dōngdū Dàshèng-shàn sì gù Zhōng-Tiānzhú guó Shànwúwèi sānzàng héshàng beeiming bingxù 大唐東都大聖善寺故中天竺國善無畏三藏和尚碑銘並序 [The Central Indian Tripitaka Master, Venerable Śubhākarasimha's Stele Inscription from the

81 We wish to thank Sam van Schaik and Agnieszka Helman-Wazny for their very helpful comments on the physical features of the fragment.

82 The extant parts of the passages are in boldface. 
Dàshèngshàn Monastery in the Eastern Capital of the Great Táng, with Preface]; ed. T.50, no. 2055 .

Dàbān nièpán jīng 大般涅槃經; tr. by Tán Wúchèn 曇無讖 (Dharmakșema, 385-433); ed. T.12, no. 371.

Dàxīngshān sì chánshī shāmén Dìnghui shīcăn 大興山寺禪師沙門定慧詩筸 [Poetic Verse by the Chán Master, Monk Dinghui of Dà Xīngshān Temple]; S.58o9.

Dàxīngshàn-sì chánshī shāmén Dìnghui zàn 大興山寺禪師沙門定惠贊; S.5809.

Fóshuō Léngqié jīng chánmén xītán zhāng 佛說楞伽經禪門悉談章 [The Siddham Chapter of the Gate of Chán [according to] the Lankkavatāra Sūtra Expounded by the Buddha; hereafter Siddham Song]; P. 2204, P.2212, P.3082, P.3099; S.4583v, Beijing niǎo 鳥64 (BDooo41-1), Dxoo492; ed. T.85, no. 2779. [Siddham Song]

Gāosēng zhuàn 高僧傳; by Huìjiǎo 慧皎; ed. T.50, no. 2059.

JDCDL; see Jingdé chuándēng lù.

Jingdé chuándēng lù 景德傳燈錄 [Record of the Transmission of the Lamp Compiled in the J̌̌ngdé Era]; comp. by Dàoyuán 道原 in 1004; ed. T.51, no. 2076. [JDCDL]

Jiūmóluóshí făshì tōngyùn 鳩摩羅什法師通韻 [Comprehensive Rhymes of the Monk Kumärajīva]; fragments of the text are preserved in S.1344.

Lañkāvatāra Sūtra; see Léngqié ābáduōluó bǎo jīng.

Léngqié ābáduōluó bǎo jīng 楞伽阿跋多羅寶經 [Lan்kāvatāra sūtra] / Léngqié jīng 楞伽 經; ed. T.16, nos. 670, 671, 672; tr. by Guṇabhadra in ca. 443; ed. T.16, no. 670.

Léngqié shīzīji 楞伽師資記 [Record on the Masters and Disciples of the Lankāvatāra]; by Jìngjué 淨覺 (683-?); P.3294, P.3436, P.3537, P.3703, P.4564, S.2O54; ed. T.85, no. 2837. Lóngkān shǒujing 龍俞手鏡 [Hand Mirror of the Dragon Niche]; 1oth century Liáo 遼 Dynasty dictionary; facsimile edition, Běijīng: Zhōnghuá shūjú 中華書局, 2006.

Mahāparinivāna Sūtra; see Dàbān nièpán jīng.

Nièpán jīng xītán zhāng 涅槃經悉曇章; composed ca. 862; manuscript in the Tōyō Bunko collection.

Shittanzō 悉曇藏; by Annen 安然; composed in ca. 881; ed. T.84, no. 2702.

Tōngyùn 通韻; see Jiūmóluóshí fǎshì tōngyùn 鳩摩羅什法師通韻.

Wǔgèng zhuăn-Nánzōng dìng xiézhèng wǔgèng zhuăn 五更轉-南宗定邪正五更轉; S.2679, S.4634, S.6o83, S.6923, S.4654, P.2045, P.227o, Beijing 咸 18, Beijing 露 6.

Wǔž̌xū biànwén 伍子胥變文; S.328.

Xïtánzi ji 悉薬字記 [A Record of Siddam Letters]; by Zhìguăng 智廣; ed. T.54, no. 2132. Yìqiè jīng yīnyì 一切經音義 [The Sound and Meaning of all the Sūtras]; by Xuányīng 玄 應 (?-649/661); ed. светA Co561163_o11. 


\section{Secondary Sources}

Anderl, Christoph. 1995. Sengchou 僧稠 (480-56o)—Studie über einen chinesischen Mediationsmeister des 6. Jahrhunderts unter besonderer Berücksichtigung seiner Bedeutung für die frühe Periode des Chan-Buddhismus. M.A. thesis. Universität Wien.

Anderl, Christoph and Osterkamp, Sven. 2017. Northwestern Medieval Chinese. In Encyclopedia of Chinese Language and Linguistics, ed. by Rint Sybesma et. al. Volume 3. Leiden: Brill: 218-229.

Boltz, Judith M. 2005. Catalogue of Non Buddhist Documents from Dunhuang in the British Library. London: IDP. (Integrated in the IDP Database; there, her contributions are marked with Boltz_1992).

Chappell, David. 1983. The Teachings of the Fourth Ch'an Patriarch Tao-hsin (580-651). In Early Ch'an in China and Tibet, ed. by Whalen Lai and Lewis R. Lancaster. Berkeley: Asian Humanities Press: 89-130.

Chaudhuri, Saroj Kumar. 2011. Sanskrit in China and Japan. New Delhi: International Academy of Indian Culture/Aditya Prakashan.

Chen Jinhua. 2011. "Esoteric Buddhism and Monastic Institutions." EBTEA: 286293.

Demieville, Paul and Jao Tsong-yi 1971: Airs de Touen-houang (Touen-houang k'iu). Mission Paul Pelliot Documents Conserves a la Biblioteque Nationale II. Paris: Éditions du Centre national de la recherche scientifique.

Dèng Wénkuān 鄧文寬 and Róng Xīnjiāng 榮新江. 1999. Dūnbó běn Chán-jí lùjiào 敦博 本禪籍錄校 [An edition of Chán texts extant in the Dūnhuáng Museum]. Nánjīng: Jiāngsū gǔjí chūbănshè 江蘇古籍出版社.

Dūnhuáng gēcí; see Rèn Bàntáng 1987.

[FDC=] Fóguāng dà cídiǎn 佛光大辭典 [Encyclopedic dictionary of the Buddha Light]. 8 volumes. Ed. by Hsing-yun 星雲. Taipei: Fóguāng chūbănshè 佛光出版社, 1989. (There is a 1993 reprint by the Commercial Press in Běijīng.)

Gomez, Luis. 1983. The Direct and the Gradual Approaches of Zen Master Mahāyāna: Fragments of the Teachings of Mo-ho-yen. In Studies in Ch'an and Hua-yen, ed. by Robert M. Gimello and Peter N. Gregory. Honolulu: University of Hawai'i Press: 69168.

Hirakawa, Akira. 1997. A Buddhist Chinese-Sanskrit Dictionary. Tokyo: Reiyūkai 霊友会. [short: Hirakawa]

Huáng Qīngpíng 黃青萍 (no date): Dūnhuáng chūtǔ Xiū xīnyào lùn lián xiěběn wénxiàn yánjiū shǐlüè jí qí yìỳ 敦煌出土 《修心要論》連寫本文獻研究史略及其意 義 [A study of the various manuscript versions of the Xiü xinnyào lùn excavated in Dūnhuáng]. Thesis (1995?). Published at: http://www.yinshun.org.tw/95thesis/95-ol.htm.

Huáng Zhèng 黃征. 2005. Dūnhuáng súzi diăn 敦煌俗字典 [A dictionary of Dūnhuáng 
vernacular character forms]. Shànghăi: Shànghăi jiàoyù chūbănshè 上海教育出版 社.

Iriya Yoshitaka 入矢義高 and Koga Hidehiko 古賀英彦. 1991: Zengojiten 禅語辞典 [Dictionary of Zen Buddhism]. Kyoto: Shibunkaku 思文閣. [short: Zengo jiten]

Jì Xiànlín 季羡林. 1995. Fànyǔ fódiǎn jí hànyì fódiăn zhōng sì liúyīn $r \bar{r}$ 及汉译佛典中四流音 rṛ̣!ḷ 问题. In: JiXiànlín Fójiàoxuéshù lùnwénji 季羡林佛敎學術 論文集: 349-390.

Karashima Seishi 辛嶋靜志. 2013. A Glossary of Kumārajīva's Translation of the Lotus Sutra 妙法蓮華經詞典. Digital Version. Taipei, Library and Information Center of Dharma Drum Buddhist College.

Kobayashi Enshō 小林圓照. 2011. “Tonkō shahon Shittan shō rui no tokuisei-Zenmon Shittan shō no tekisuto kenkyu 敦煌写本 $<$ 悉曇章 $>$ 類の特異性一『禅門悉談章』 のテキスト研究 [The special features of the Dūnhuáng manuscript of the Shittan shō-Textual Studies on the Siddham Chapter of the Chán School]." Indōgaku bukkyōgaku kenkyū 印度学仏教学研究 59, no. 2: 36-44.

Kōsetsu Bukkyōgo daijiten; see Nakamura 2001.

Lǐ Zhìxián 李志賢 (ed.). 2011. Zhōngguó cǎoshū dàzidiǎn 中國草書大字典 [A dictionary of Chinese cursive script]. Shànghǎi: Shànghǎi shūhuà chūbǎnshè 上海書畫 出版社.

Mài Wénbiāo 麥文彪 2013: “Fuan-ju ni okeru Shittan jibo ni tsuite: Bukkyō shingon no chūgokuka no ichirei 「普庵咒」における悉曇字母について: 佛呚眞言の中國化 の一例 [Concerning the Siddham alphabet in the Fuan-ju: a case of sinization of Buddhist esoteric teachings].” Tōhō gakuhō 東方學報 88: 189-219.

McRae, John. 1986. The Northern School and the Formation of Early Ch'an Buddhism. Honolulu: University of Hawai'i Press.

Meisig, Konrad and Meisig, Marion. 2012. A Buddhist Chinese Glossary / BuddhistischChinesisches Glossar. Wiesbaden: Harrassowitz.

Nakamura Hajime 中村元. 1975. Bukkyōgo daijiten 仏教語大辭典 [Encyclopedic dictionary of Buddhist terms]. Tōkyō: Tōkyō shoseki 東京書籍. [short: Nakamura]

Nakamura Hajime 中村元. 2001. Kōsetsu bukkyōgo daijiten 広說佛教語大辞典 [An expanded dictionary of Buddhist terms]. Tōkyō: Tōkyō shoseki 東京書籍. [short: Kōsetsu Bukkyōgo daijiten].

Ráo Zōngyí 饶宗颐. 1993. Chánmén Xïtánzhāng zuòzhě biàn 禅门悉是章作者辨 [A discussion concerning the author of the Xìtánzhāng of the Chán School]. In Fànxuéjí 梵学集, ed. by Ráo Zōngyí 饶宗䝠. Shànghăi: Shànghǎi gǔjí chūbǎnshè 上海古籍出 版社.

Rèn Bàntáng 任半塘. 1987: Dūnhuáng gēcízǒngbiān 敦煌歌辭總編 [An edition of Dūnhuáng songs and $c i ́$ ]. Shànghăi: Shànghǎi gǔjí chūbănshè 上海古籍出版社.

Takise Shōjun 瀧瀬尚純 20og: “Bussetsu Ryōga kyō zenmon Shittan shō ni tsuite 『仏説 楞伽経禅門悉談章』について [Concerning the Siddham Chapter of the Chán teach- 
ing of the Lañkāvatāra sūtra]." Indogaku bukkyōgaku kenkyū 印度学仏教学研究 57, no. 2: 179-183.

Takise Shōjun 瀧瀬尚純 2010: “Jōkaku hasen ni giserareru futatsu no Shittan shō 浄覚派 撰に擬せられる二つの『悉談章』."Rinzai-shū Myōshin-ji ha kyōgaku kenkyū kiyō 臨済宗妙心寺派教学研究紀要 8: 77-99.

Wáng Yàróng 王亞榮 (ed.). 1986. Dàxīngshàn sì 大興善寺. Xīān 西安: Sānqín chūbănshè 三秦出版社.

Wáng Zhìpéng 王志鹏. 2005. “Cóng Dūnhuáng gēcí kàn Táng-dài Dūnhuáng dìqū chánzōng de liúzhàn yǔ fāzhăn 从敦煌歌辞看唐代敦煌地区禅宗的流传与发展 [A study of the transmission and development of the Chán School in the Dūnhuáng area during the Táng Dynasty based on the songs from Dūnhuáng]." Dūnhuáng yánjīu 敦煌 研究 6: 96-101.

Zengaku daijiten 禅学大辞典. 1978. Tōkyō: Daishukan shoten 大修館書店.

Zengo jiten; see Iriya and Koga 1991.

Zhōngguó căoshū dàzidiǎn; see Lǐ Zhìxián 2011.

Zhōu Guăngróng 周广荣. 2001. "Dūnhuáng Xìtánzhāng gēcí yuánliú kăolüè 敦煌《悉县 章》歌辞源流考略 [Thoughts about the origin and development of the Xïtánzhāng from Dūnhuáng]." Dünhuáng yánjiū 敦煌研究 67: 141-150. 